\title{
Changes in Cave Sedimentation Mechanisms During the Late Quaternary: An Example From the Lower Cerovačka Cave, Croatia
}

\begin{abstract}
Tomislav Kurečić ${ }^{1}$, Neven Bočić ${ }^{2 *}$, Lara Wacha ${ }^{1}$, Koraljka Bakrač ${ }^{1}$, Anita Grizelj ${ }^{1}$, Dinko Tresić Pavičić ${ }^{3}$, Christopher Lüthgens ${ }^{4}$, Andreja Sironić ${ }^{5}$, Siniša Radović ${ }^{6}$, Loris Redovniković ${ }^{7}$ and Markus Fiebig ${ }^{4}$
\end{abstract}

${ }^{1}$ Department of Geology, Croatian Geological Survey, Zagreb, Croatia, ${ }^{2}$ Department of Geography, Division of Physical Geography, Faculty of Science, University of Zagreb, Zagreb, Croatia, ${ }^{3}$ Kaducej d.o.o., Split, Croatia, ${ }^{4}$ Institute of Applied Geology, University of Natural Resources and Life Sciences (BOKU), Vienna, Austria, ${ }^{5}$ Laboratory for Low-level Radioactivities, Division of Experimental Physics, Ruđer Bošković Institute, Zagreb, Croatia, ${ }^{6}$ Institute for Quaternary Palaeontology and Geology, Croatian Academy of Sciences and Arts, Zagreb, Croatia, ${ }^{7}$ Department of Applied Geodesy, Faculty of Geodesy, University of Zagreb, Zagreb, Croatia

OPEN ACCESS

Edited by: Aurel Perşoiu,

Romanian Academy, Romania

Reviewed by: Andrea Zerboni,

University of Milan, Italy Christos Pennos,

University of Bergen, Norway

*Correspondence: Neven Bočić nbocic@gmail.com

Specialty section: This article was submitted to Quaternary Science, Geomorphology and Paleoenvironment, a section of the journal Frontiers in Earth Science

Received: 25 February 2021 Accepted: 15 June 2021 Published: 30 June 2021

Citation:

Kurečić $T$, Bočić N, Wacha L, Bakrač K, Grizelj A, Tresić Pavičić D, Lüthgens $C$, Sironić A, Radović S, Redovniković $L$ and Fiebig M (2021)

Changes in Cave Sedimentation

Mechanisms During the Late Quaternary: An Example From the Lower Cerovačka Cave, Croatia.

Front. Earth Sci. 9:672229.

doi: 10.3389/feart.2021.672229
During archeological excavations in the Lower Cerovačka Cave (Mt. Velebit, Croatia), the test trench penetrated to a depth of $1.8 \mathrm{~m}$. An undisturbed sequence of sediments was exposed. Considering that caves represent highly efficient sediment traps it was possible to recognize changes in the depositional mechanisms during the Pleistocene-Holocene period. Using the multiproxy approach, the mineralogical, petrographic, and biostratigraphic characterization of the cave sediments was performed. Facies analysis revealed several stages in the development of the clastic filling of cave channels. Allochthonous origin of the sediment was assumed. Sedimentation took place under various conditions from pronounced cold and dry climate during Pleistocene stages in the base of the profile, to humid periods with anthropogenic influence during the Holocene at the very top of the profile. Although traditionally these sediments were believed to be of a Pleistocene age, here for the first time a stratigraphic calibration of the profile has been performed based on luminescence dating of detrital cave sediments and radiometric dating of speleothems.

Keywords: cave sediments, facies analysis, provenance, numerical dating, palynofacies, Ursus spelaeus, Dinaric karst

\section{INTRODUCTION}

Situated in the locus typicus of the Dinaric karst (Zupan Hajna, 2019) within the NE slopes of Mt. Crnopac (SE part of the Velebit massif in Croatia) (Figures 1A,B), the Cerovačke Caves represent a network of subhorizontal hydrologically inactive cave channels (Figures $2 \mathrm{~A}, \mathbf{B}$ ) in today's vadose zone. There are three Cerovačke caves, namely Lower, Middle and Upper Cerovačka Cave (LCC, MCC and UCC). LCC was discovered in 1913 (Malez, 1956, 1958) during the construction of the railroad. The caves have been the focus of research for many speleologists and other geoscientists ever since. Because of the scientific interest, as well as exploitation interest related to the geo-heritage and tourist potential of the cave, intensive cave surveying was conducted, combined with paleontological and archaeological excavations. That research gave insight into the rich cave history, as evidenced by 


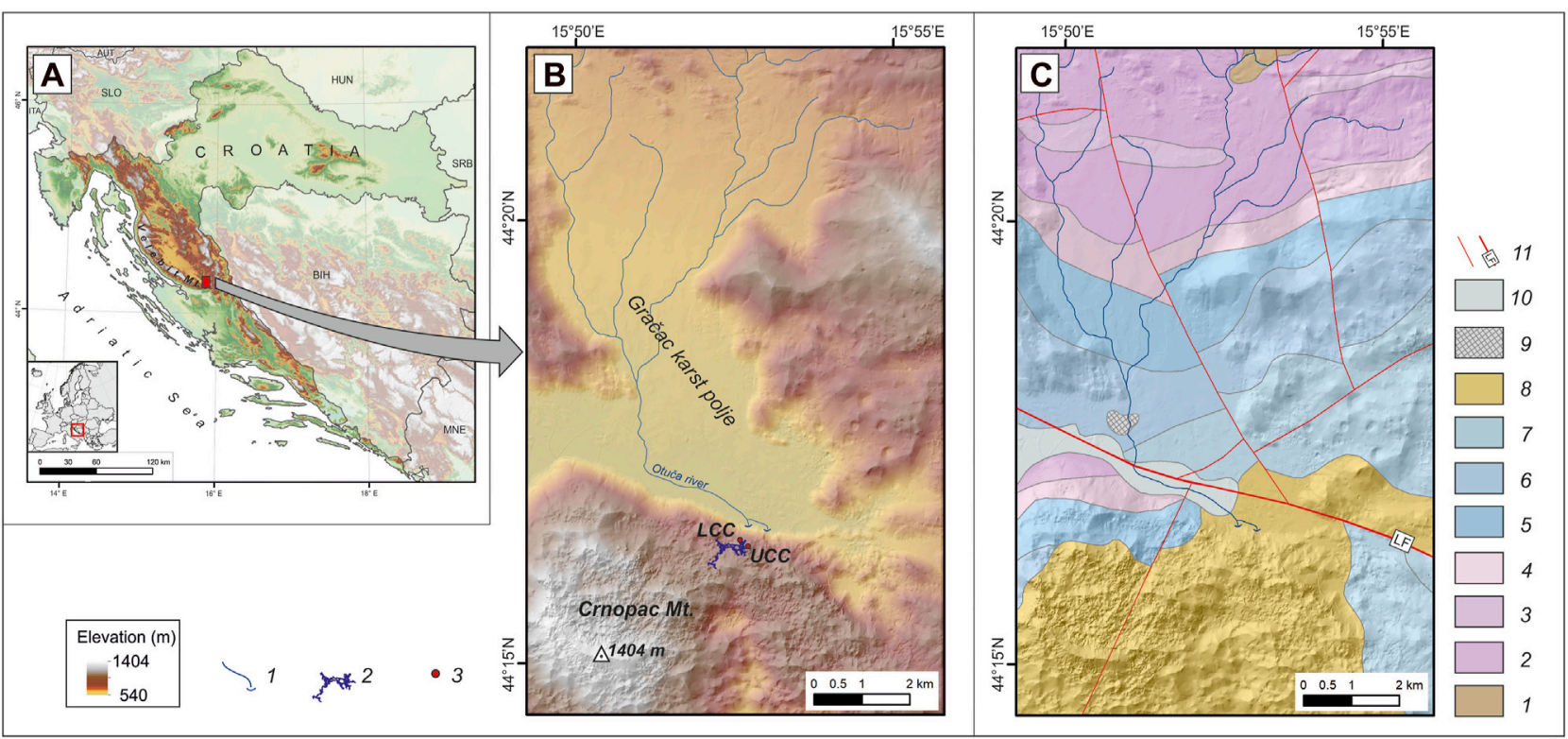

FIGURE 1 | (A) Geographic position of the Cerovačke Caves, (B) Elevation map of the surrounding area, legend: 1-surface streams with ponors, 2-cave chanells of Lower and Upper Cerovačka Cave, 3-entrance positions of Lower (LCC) and Upper (UCC) Cerovačka Cave, (C) Geological map of the surrounding area, sources: Geological map of Croatia 1:300.000 (Croatian Geological Survey, 2009), Basic geological map of Croatia 1:100.000, sheet Obrovac (Ivanović et al., 1973), Basic geological map of Croatia 1:100.000, sheet Udbina (Šušnjar et al., 1973), legend: 1 - clastic rocks (C, P), 2 - carbonate rocks $\left(T_{2}\right), 3-$ clastic-pyroclastic rocks $\left(T_{3}\right)$, 4-dolomites $\left(T_{3}\right), 5$ - limestones and dolomites $\left(\mathrm{J}_{1}\right), 6$-thick layered limestones and dolomites $\left(\mathrm{J}_{2}\right), 7$ - limestones and dolomites $\left(\mathrm{J}_{3}\right), 8$ - carbonate $(\mathrm{Jelar})$ breccia $(\mathrm{Pg}$, $\mathrm{Ng})$, 9-alluvial deposits (Q), 10-Terra Rossa (Q), 11-faults, LF-Lika fault.

findings of large Pleistocene fossil mammals (Malez, 1960a; 1965a). Consequently, excavation campaigns resulted in the first available data of cave channel sediment infill and provenance of cave detrital sediments (e.g., Ivanović et al., 1976). First interpretations suggest that these sediments represent products of host rock weathering, deposited after the caves lost their ponor (swallow hole) function during the uplift of the mountain and lowering of the Gračac karst polje level (Malez, 1965b).

In recent years, the interest in revitalizing the tourist potential of the LCC intensified. Following requirements prescribed by the Conservation Department in Zadar (Croatia), new archaeological research in the LCC was conducted during 2019. Excavations included the area of the cave with archaeological potential, endangered by construction works along the new visitor pathway. The main archaeological excavation area was placed along the route of the new pathway, spanning $120 \mathrm{~m}$ from entrance. Three distinctive phases of human occupation were determined within the excavation sites of the LCC, above the geological record (Tresić Pavičić, 2020). The latest phase is attributed to the modern period, from the discovery of the cave in 1913 until today, and includes various features such as existing pathway, trenches for electrical cables and archaeological and geological test trenches from previous excavations. The medieval phase within the cave was represented by a small number of finds dated to the 13th century (Tresić Pavičic, 2020) when the cave was used sporadically, probably as a shelter. The earliest and archeologically most significant phase of human occupation represented in the excavated area, corresponds to features and finds from the Late Bronze Age period which in the area of Lika roughly corresponds to the period from the 14th to 10th century BC (Blečić-Kavur, 2014; Bakarić, 2017). The data collected suggest that the cave was used for food storage and as a temporary dwelling in specific circumstances such as extreme weather conditions during the Late Bronze Age. The archaeological remains are numerous and well documented. However, there has been a significant lack of any new geological research within the cave since the seventies.

The sediment profile (DC-SP) investigated within our research is situated within a test trench placed $120 \mathrm{~m}$ from the cave entrance at the end of archaeological excavation area (Figure 2B). Since the test trench penetrated to a depth of $1.8 \mathrm{~m}$, an undisturbed sequence of sediments was exposed. At the site, the Late Bronze Age and Modern Period features were found within the investigated profile (Figure 3A). However, the majority of the profile represents geological strata of unknown origin and age. The aim of this study, therefore, is to determine the provenance of sediments, and the type and degree of changes in the environment during the time of deposition of clastic cave sediments within the main channel of the LCC. A multiproxy research approach was applied to the sediment including detailed sedimentological and mineralogical analysis. The lithofacies analysis of the detrital cave sediments was used to answer questions regarding the deposition mechanisms in specific conditions during the Pleistocene. Mineralogical analyzes are applied to get insight into the provenance of the cave sediments. Macropaleontological analysis was performed for a detailed determination of the excavated fossil bones as well as 


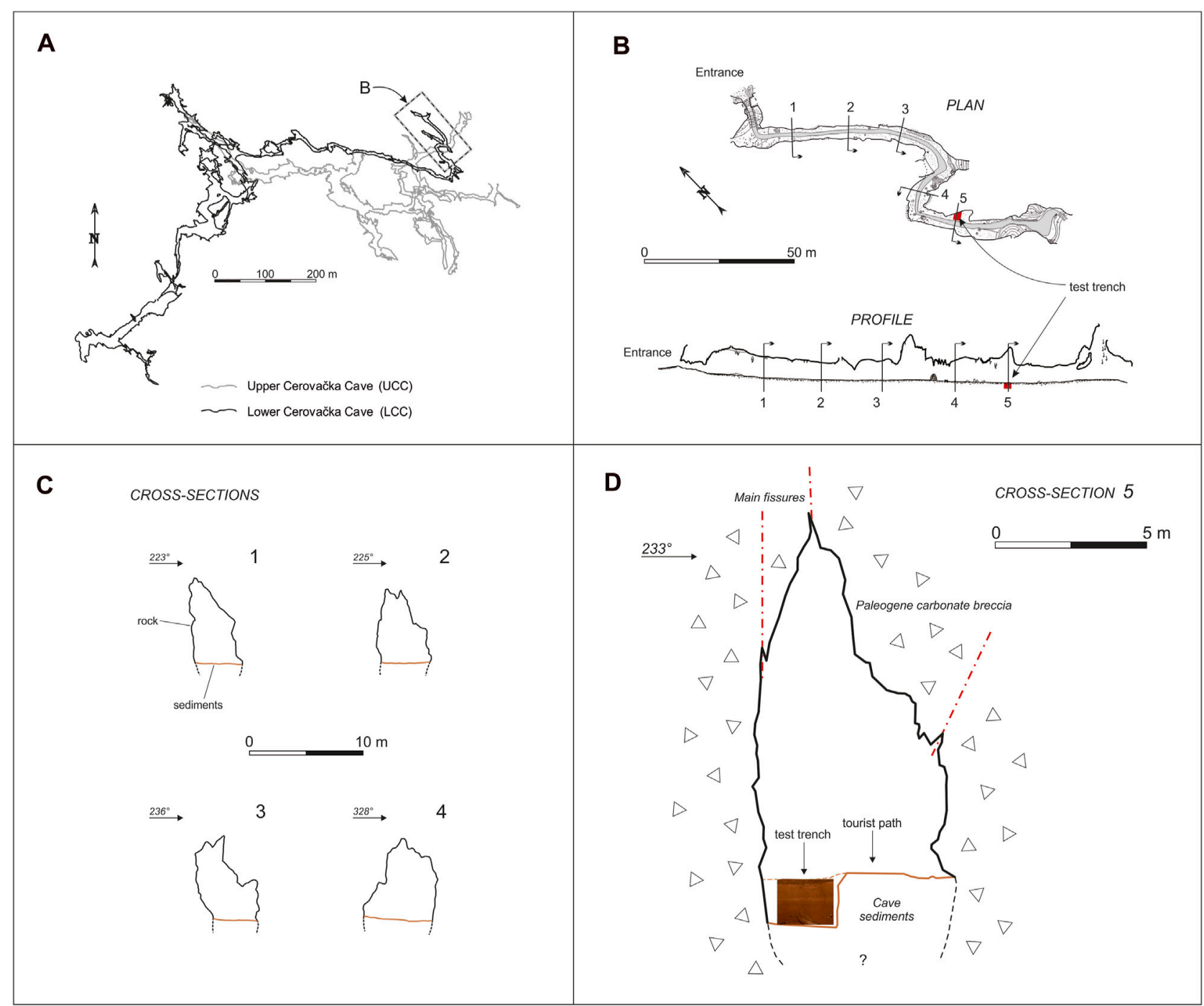

FIGURE 2 | (A) Simplified plan view of the Upper and Lower Cerovačka Cave, (B) plan view of the entrance part of the Lower Cerovačka Cave with the marked position of the researched test trench (cave survey according Bočić et al., 2016), (C) selected cross-sections (1-4), and (D) cross-section of the cave channel at the location of the test trench.

palynological analysis to determine the palynofacies. To establish the time frame and stratigraphic calibration of the investigated profile, luminescence dating of detrital cave sediments was performed and supported with radiometric dating of speleothems found within the sediment sequence. Furthermore, a comparison with available data on similar (spatio-temporal) sedimentary profiles will be given.

\section{GEOLOGICAL AND GEOMORPHOLOGICAL SETTING}

Velebit Mt. is a part of the Dinaric mountain system and the longest mountain range in Croatia (Figure 1A). Cerovačke Caves are located on the northern slope of its extreme southeastern part, Crnopac (Figure 1B). To the north of Crnopac lies the Gračac karst polje. In the structural-geological sense, the area of the Gračac polje forms an anticline with Paleozoic clastites in their core. Around them Mesozoic sediments spread periclinally (Sokač et al., 1976; Šušnjar et al., 1973; Ivanović et al., 1973, 1976). Triassic dolomites and clastites and Jurassic dolomites predominate at the surface. The youngest are Quaternary Terra Rossa and alluvial deposits recorded at the bottom of the polje (see Figure 1C for details). This lithology causes the bottom of the Gračac polje to act as a hydrogeological barrier. A surface drainage network has developed on its surface with a general drainage direction to the south. The main stream is the Otuča River, which forms a ponor zone in the southern, deepest part of the field (Figures 1B,C). The Otuča drainage system superficially drains an area of about $90 \mathrm{~km}^{2}$ as well as the underground karst water that converges to the polje from the surrounding hills. The lowest point of the field is at an elevation of $544 \mathrm{~m}$. South of the 


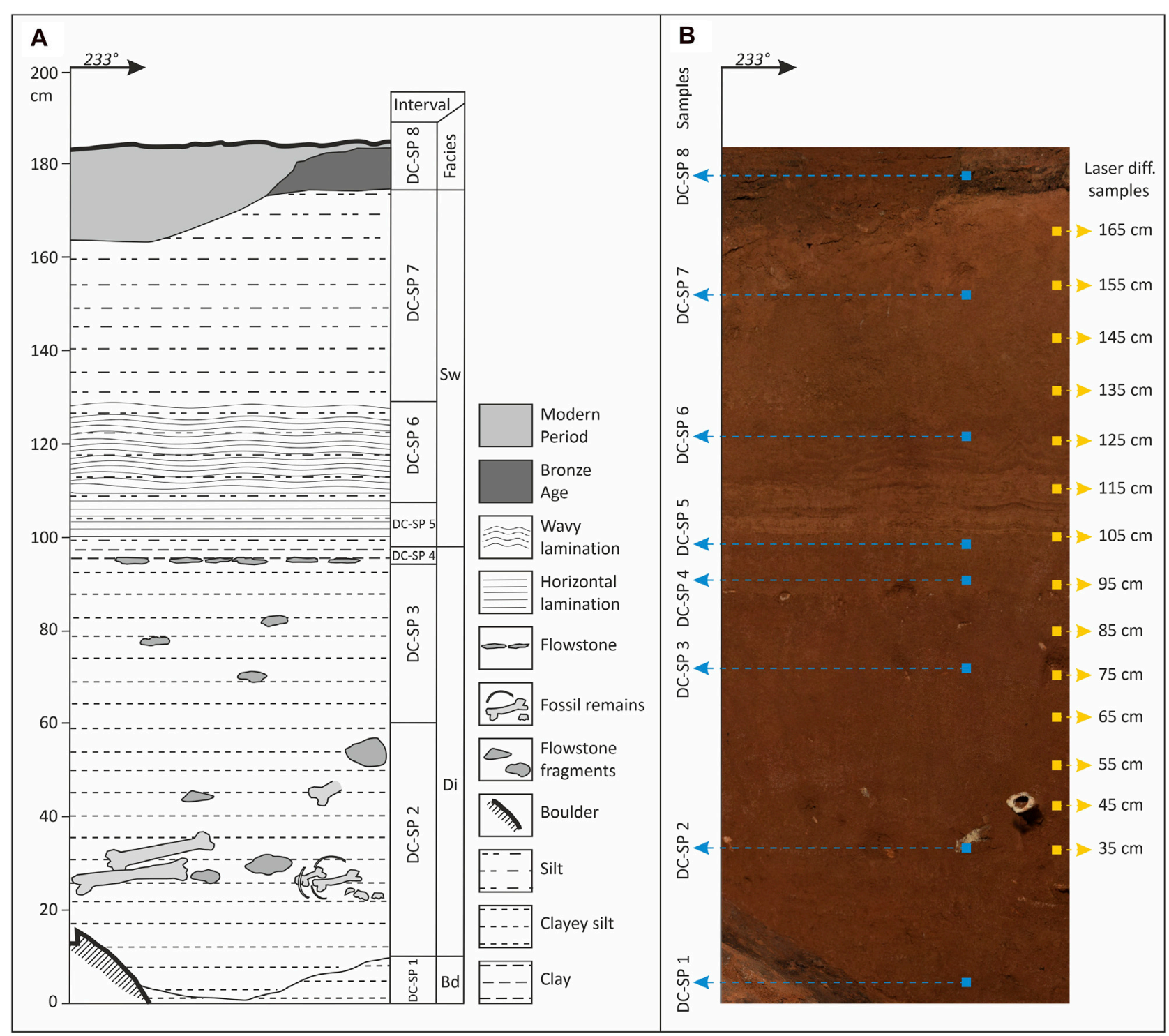

FIGURE 3 | Sedimentary log and photo of the investigated profile DC-SP within the archaeological excavation site in the Lower Cerovačka Cave (A) Sedimentary log with indicated main structural and lithological features, (B) photo of profile and indicated position of sampling spots (on the left side-bulk analysis of described intervals; on the right side-high-resolution granulometric analyses).

Gračac polje rises the Crnopac massif (1,404 m), separated by the Lika fault (Figures 1B,C). Crnopac is a part of the main ridge and tectonic unit Velebit. Its structure is dominated by Jurassic and Cretaceous carbonate rocks separated by paleo-relief boundaries from overlaying Paleogene carbonate breccias (Ivanović et al., 1973, 1976) known as Jelar breccia (Bahun, 1963, 1974). Areas built up of Jelar breccias like the Northern Velebit are intensively karstified, with a large number of dolines and deep caves, including Lukina jama, the deepest cave in the Dinarides (Bočić et al., 2019). Similar to the Northern Velebit, the Crnopac area is also extremely karstified. The area is characterized by large, steep, and numerous dolines whose maximum density reaches 93 dolines per $\mathrm{km}^{2}$ (Marković et al., 2016). More than 200 caves have been explored in the area, the largest of which is the Crnopac Cave System (CCS) (Barišić, 2017), which is the longest cave in the Dinarides and 67th longest cave in the world, measuring $53.3 \mathrm{~km}$ in length (Caver Bob, 2021; Croatian Mountaineering Association, 2021).

Sinking waters from the Gračac polje flow underground through the Crnopac massif toward the south, to the valleys of the Krupa and Zrmanja rivers. These allogenic flows influence the formation of cave systems. Due to the uplifting of the Crnopac massif cave channels form at several levels. The speleogenesis of the Crnopac massif is also influenced by autogenous water, which has a vertical circulation through a deep unsaturated zone (Kuhta and Stroj, 2005).

This area has the climate type $\mathrm{Cfb}$ (temperate humid with warm summer) (Filipčić, 1998). Basic climatological 
characteristics of the area are visible through the basic data of the Gračac meteorological station for the period 2004-2014: (i) the average annual air temperature is $9.9^{\circ} \mathrm{C}$ and the mean annual precipitation is $1,960 \mathrm{~mm}$ and (ii) the warmest month is July $\left(19.9^{\circ} \mathrm{C}\right)$, but the highest mean monthly precipitation is in December (283 mm) (Czuppon et al., 2018).

All three known caves at the investigated site (UCC 4,035 m, LCC 4,048 m, MCC, $390 \mathrm{~m}$ long) are located in the ponor (input) zone of the Crnopac karst system above the level of the karst polje, i.e., the currently active ponors. All three caves are formed in Paleogene carbonate (Jelar) breccias (Figures 1B,C).

The LCC is a predominantly horizontal branchwork cave (sensu Palmer, 1991). The entrance altitude is $630 \mathrm{~m}$, i.e., about $80 \mathrm{~m}$ higher than the active ponors at the edge of the karst polje. The cave can be morphologically divided into two parts. In the northern part, the channels run mainly in NW-SE direction, following the main fold and thrust belt direction of the External Dinarides (Tari, 2002; Schmid et al., 2008; Korbar, 2009). Here the channels are relatively narrower and rarely exceed $5 \mathrm{~m}$. In the southern part of the cave, which extends toward the SW, the channels are much wider and often exceed $10 \mathrm{~m}$ in width (Figure 2A). The formation of the cave is most likely related to the function of the karst conduit of sinking waters from the Gračac karst polje. The investigated test trench is located in the main channel at a distance of about $120 \mathrm{~m}$ from the entrance, measures about $3 \times 3 \mathrm{~m}$ in plan and is $1.8 \mathrm{~m}$ deep (Figure 2B).

\section{MATERIALS AND METHODS}

The cave survey was the starting point to obtain data on the morphology of the cave. The part of the cave open for visitors (about $700 \mathrm{~m}$ long) was surveyed at a scale of $1: 200$, the rest of the cave at a scale of 1: 500. The survey was made in the UIS-5-4-BC mapping grade (Häuselmann, 2011). A standard procedure was used to determine the relative position of survey points by measuring the distance, azimuth and inclination angle. The Leica hand laser distometer and Suunto clino-compas were used. The starting point outside the cave was stabilized with a GNSS receiver. Additional data on the morphology of the investigated part of the cave were obtained by laser scanning. The first laser scanning of LCC was performed in the period from January 15 to 17,2016 . At that time, two geodetic bases were established, one in front of and the second inside of the cave. The Faro Focus3D X 330 laser scanner, the Topcon HiPer SR GNSS receiver and two total stations (TOPCON GTS 105N and Cygnus 2LS) were used for the geodetic survey of the LCC. The laser scanning was performed again on June 13th and 14th, 2019. but this time strong lighting was used and panoramic $360^{\circ}$ photographs were collected during the scan to obtain a colored point cloud. Point clouds obtained by the photogrammetric method during archaeological research are connected to the new colored point cloud and presented within this paper as 3D supplement (Supplementary Material S1). Leica Cyclone 3DR software was used to visualize the obtained data and to create a characteristic profile.
Archaeological excavations were carried out with hand tools following stratigraphic principles, and standard archaeological field records were kept. A detailed catalog of methods and archaeological findings is given by Tresić Pavičić and Burmaz (2020) and Tresić Pavičić (2020). Sedimentological field data and sampling were acquired within the archaeological test trench.

For a detailed sedimentological analysis individual layers and lithofacies units were recognized below the archaeological layer (Figure 3A). The nomenclature for the established lithofacies units was based on Bosch and White (2004). All layers were sampled (Figure 3B). The grain-size of the sediment was determined on five bulk samples from each observed lithological unit using the areometric method (Figure 3B; Samples DC-SP 2, 3, 5, 6, 7) while high-resolution grain-size (in $10 \mathrm{~cm}$ resolution) was determined using the laser diffraction method. A total of 14 samples were analyzed with a Shimadzu Laser Diffraction Particle Size Analyzer SALD-2300 to determine the detailed dynamics of vertical changes in the particle size distribution (Figure 3B; Samples DC-SP 35-165 cm). $0.1 \mathrm{~g}$ of a dry representative sample was isolated for the analysis. The samples were treated with a $4 \%$ solution of tetra-sodium diphosphate decahydrate $\left(\mathrm{Na}_{4} \mathrm{P}_{2} \mathrm{O}_{7} \cdot 10 \mathrm{H}_{2} \mathrm{O}\right)$ and deionized water against coagulation and dispersed for at least $6 \mathrm{~h}$ on a shaker. Each measurement was repeated five times and an average value was used for the grain-size distribution. The sediment was classified according to Trefethen (1950).

To get insight in the composition of the sediment and determine the provenance of the material, the modal (heavy and light minerals) and XRPD analyses were performed. For the separation of heavy and light minerals, the $0.09-0.16 \mathrm{~mm}$ fraction of five samples was used (Figure 3B; Samples DC-SP 2, 3, $5,6,7)$. Samples were treated with $10 \% \mathrm{HCl}$ to remove the carbonates, and washed with $\mathrm{H}_{2} \mathrm{O}$ in an ultrasonic bath. The grains were separated using sodium polytungstate $(\rho=$ $\left.2.8 \mathrm{~g} \mathrm{~cm}^{-3}\right)$. Thin slides were prepared from the separated material, and the composition was determined by counting up to 300 grains per sample using a Leitz Orthoplan polarizing microscope (Mange and Maurer, 1992). Typical mineral groups were isolated and their characteristics and relative proportions in the samples were described. Due to the low content of transparent heavy minerals (THM) within the heavy mineral fraction (HMF), real percentages and statistical analysis are not shown.

The mineral composition of seven cave sediment samples and a bone fragment were determined by X-ray powder diffraction (XRPD) (Figure 3B; Samples DC-SP 1-bone, 1-7-sediment). The samples were grinded, sieved through a $0.063 \mathrm{~mm}$ sieve and the $<2 \mu \mathrm{m}$ fraction was separated using the centrifuge method (Krumm, 1994). Oriented mounts from $<2 \mu \mathrm{m}$ fraction were prepared. Oriented samples were treated with following treatments: a) air drying, b) saturation with $\mathrm{K}^{+} \mathrm{c}$ ) saturation with $\mathrm{Mg}^{2+}$ d) $\mathrm{Mg}^{2+}$ saturation and ethylene-glycol solvation, e) $\mathrm{K}^{+}$saturation and ethylene-glycol solvation, $\mathrm{f} \mathrm{Mg}^{2+}$ saturation and glycerol solvation, g) $\mathrm{K}^{+}$saturation and DMSO solvation, h) heating more than $1 / 2$ hour to 400 and $550^{\circ} \mathrm{C}$, i) treating with $\mathrm{HCl}$ (18\%, $24 \mathrm{~h})$ (Weaver, 1967; Starkey et al., 1984; Moore and Reynolds, 1997) and XRD patterns were recorded. The measurements were performed using the Philips vertical 
goniometer (type $\mathrm{X}^{\prime}$ Pert) equipped with a $\mathrm{Cu}$ tube under the following experimental conditions: $45 \mathrm{kV}, 40 \mathrm{~mA}$, PW 3018/00 PIXcel detector, primary beam divergence $1 / 4^{\circ}$, continuous scan (step $0.02^{\circ} 2 \theta / \mathrm{s}$ ). The interpretation of XRPD was obtained using HIGH SCORE PLUS (2016) calculation and PDF-4 / Minerals (2020) databases. The semi-quantitative analysis was performed using the procedure described by Schultz (1964).

Palynological analyses were carried out on four samples collected from the lower and upper part of the section (Figure 3B; Samples DC-SP 1, 2, 7, 8). Standard palynological processing techniques were used to extract the organic matter (e.g., Moore et al., 1991; Wood et al., 1996). The samples were treated with $4 \%$ solution of tetra-sodium diphosphate decahydrate $\left(\mathrm{Na}_{4} \mathrm{P}_{2} \mathrm{O}_{7} \cdot 10 \mathrm{H}_{2} \mathrm{O}\right)$ against coagulation, cold $\mathrm{HCl}$ (15\%) and $\mathrm{HF}$ (40\%), removing carbonates and silica, respectively. Heavy liquid $\left(\mathrm{ZnCl}_{2}, \rho>2.1 \mathrm{~kg} / \mathrm{l}\right)$ was used to separate the organic matter from the undissolved inorganic components. The organic residue was sieved through a $10 \mu \mathrm{m}$ mesh. For palynofacies analysis slides were mounted in glycerin and, for palynomorphs analysis in silicon oil. Microscopic analyses were performed using the Olympus BH-2 and Leica DM2500 microscope (Croatian geological survey). Photomicrographs were taken using an AmScopeTM camera adapter connected to the AmScope v.3.7 camera software and Leica MC190 HD camera connected to the Leica LAS EZ software. The palynofacies analyses were performed according to the classifications proposed by Tyson (1995) and Sebag et al. (2006). Three categories of organic matter (OM) were used: (1) phytoclasts: opaque phytoclasts (OP) and ligno-cellulosic debris (LcD), which can be preserved as cuticles and membranes (CM), transparent (TLC), altered (ALC), amorphous (AP) or gelified particles (GP), (2) Amorphous organic matter (AOM) and (3) palynomorphs. Minimum 500 particles of OM were counted per sample. Results were plotted in OM percentage abundance diagram and diagram presenting the relation between preserved/transformed phytoclasts and AOM to characterize the palaeoenvironment.

Macropaleontological analyses were performed on faunal remains collected during the research. The material was dry sieved on site using a mesh size of $6 \times 6 \mathrm{~mm}$, bagged and named. In the laboratory the faunal remains were washed and dried and a detailed palaeontological analysis was conducted at the Institute for Quaternary Palaeontology and Geology in Zagreb. During the anatomical and taxonomical analysis, the fossil remains were compared with the fossil and recent comparative collection stored at the Institute. This was followed by a detailed taphonomic study. All bone and teeth fragments were carefully examined with a hand lens $(\times 10$ magnification) looking for any bone modifications that could indicate butchery, gnawing, and other taphonomic traces as direct indicators of different agencies responsible for the accumulation and preservation of the skeletal material. Due to a relatively modest number of identified remains (873), taxonomic representation and element frequency were quantified using NISP (Number of Identified Specimens; Lyman, 1994).

The luminescence dating method was applied on two cave sediment samples to establish a chronological framework of the deposits (Figure 3B; Samples DC-SP 3 and 7). The samples were taken using stainless steel cylinders driven into the freshly cleaned sediment and sealed light tight after sampling. Additional samples for radionuclide determination were taken in the direct surroundings of the luminescence samples. During sample preparation, the ends of the cores were removed, because of potential light exposure during sampling. Since detrital cave sediments as water-lain sediments are known to be prone to incomplete bleaching (insufficient light exposure of the sediment during transport and before burial), the obtained ages are often overestimated. In luminescence dating, reliable methods for the detection and correction of the effects of incomplete bleaching are available. However, a basic restriction is that measurements have to be conducted on subsamples (aliquots) containing only small numbers of grains, ideally down to the single grain level. For that reason, single quartz and potassium-rich feldspar grains (usually between 63-300 $\mu \mathrm{m}$ ) were extracted from the collected samples. Sample preparation and measurements were conducted at the Vienna Laboratory for Luminescence dating (VLL) using standard methods (Lüthgens et al., 2017; Rades et al., 2018). After sample preparation, no significant amount of coarse grains could be extracted from sample DC-SP 7 (VLL0496-L), while a minimal number amount of coarse grains could be retrieved from sample DC-SP 3 (VLL-0495-L). All subsequent analyses could therefore only be conducted for the latter sample. In contrast to potassium-rich feldspar, it is known that only a small fraction of quartz grains (usually $<10 \%$, but frequently also down to only few percent) does emit a luminescence signal suitable for dating (e.g., Lüthgens et al., 2011). Given the very small amount of grains available for measurements and previous results showing rather low quartz luminescence sensitivity in the broader area (e.g., Zhang et al., 2018), single grain measurements on potassiumrich feldspar as the only dosimeter was the method of choice in this study.

A single grain, post infrared, infrared stimulated single aliquot regenerative dose protocol (SG pIRIR $_{225}$ SAR, e.g., Reimann et al., 2012; Garcia et al., 2019 but modified to include the pIRIR225 signal) was applied for the determination of the equivalent dose. Measurements were conducted at the VLL on a RIS $\varnothing$ DA-20 luminescence reader system (Bøtter-Jensen et al., 2000, 2003) equipped with an infrared laser $(830 \mathrm{~nm})$ for stimulation of the single-grain luminescence signals, which were detected through a LOT/Oriel D410/30 interference filter. For laboratory dosing, the system is equipped with a ${ }^{90} \mathrm{Sr} /{ }^{90} \mathrm{Y}$ beta source delivering a dose of about $0.1 \mathrm{~Gy} / \mathrm{s}$. Dose recovery experiments were conducted for both luminescence signals measured in the IRIR $_{225}$ dose protocol [stimulated at $50^{\circ} \mathrm{C}\left(\mathrm{IR}_{50}\right)$ and at $225^{\circ} \mathrm{C}\left(\mathrm{pIRIR}_{225}\right)$ ]. The results showed agreement with unity within the error (rejection criteria: recycling/recuperation in percent of the natural signal/test dose error $=30 / 30 / 10 \%$ ), proving the suitability of the protocol. Whenever using feldspar as a dosimeter, the effects of anomalous fading (athermal signal loss over time, Wintle 1973) must be considered. Fading experiments were conducted using the approach of Auclair et al. (2003) but modified to also include the pIRIR 225 signal. 
Naturally occurring radionuclides contributing to the doserate (decay chains of ${ }^{238} \mathrm{U}$ and ${ }^{232} \mathrm{Th}$, and ${ }^{40} \mathrm{~K}$ ) were measured using low-level, high-resolution gamma spectrometry on a Baltic Scientific Instruments high purity Germanium (HPGe) p-type detector ( $52 \%$ efficiency) after storage of the sample of more than 4 weeks. The sample were found to be in secondary secular equilibrium. The overall doserates and age calculations were conducted using the software ADELE (Kulig, 2005).

Radiocarbon dating method was applied on a speleothem and bone found in the sediment succession. Radiocarbon dating was performed by accelerator mass spectrometry (AMS). Samples were prepared into graphite targets at the Ruđer Bošković Institute (RBI, Croatia). The bone sample of Ursus spelaeus (DC-SP-2, LCC, sample ID number Z-7351) was precleaned using acid-base-acid wash and collagen extraction (Longin 1971). However, the amount of collagen in the bone was below $0.1 \%$, which indicated that the carbon in the collagen was too degraded for radiocarbon dating (Marom et al., 2013). The speleothem sample (DC-SP-4/1, LCC, ID number Z-7352) was cut, and about $200 \mathrm{mg}$ of powder were scraped off the surface. The powder was hydrolyzed to $\mathrm{CO}_{2}$ in a vacuum rig using $4 \%$ $\mathrm{HCl}$. An aliquot of the obtained $\mathrm{CO}_{2}$ was sealed in a pyrex tube for ${ }^{13} \mathrm{C}$ composition analysis on the isotope ratio mass spectrometer (IRMS). Another aliquot of the $\mathrm{CO}_{2}$ in reaction with zinc was reduced to graphite for radiocarbon AMS analysis (Krajcar Bronić et al., 2010; Sironić et al., 2013). The sample ${ }^{14} \mathrm{C} /{ }^{13} \mathrm{C}$ ratio was measured on a $0.5 \mathrm{MeV}$ AMS and ${ }^{13} \mathrm{C} /{ }^{13} \mathrm{C}$ ratio $\left(\delta^{13} \mathrm{C}\right)$ on isotope ratio mass spectrometer (IRMS), at the Center for Applied Isotope Studies, University of Georgia (CAIS, United States). $\delta^{13} \mathrm{C}$ values are expressed in per mil relative to VPDB. Measured ${ }^{14} \mathrm{C} /{ }^{13} \mathrm{C}$ ratios were corrected for isotope fractionation using the corresponding $\delta^{13} \mathrm{C}$ values measured by IRMS and normalized to $-25 \%$ VPDB and presented as $F^{14} \mathrm{C}$ and the ${ }^{14} \mathrm{C}$ age before present (BP) (Stuiver and Polach, 1977; Reimer et al., 2004). Radiocarbon age was rounded of digits in accordance with the recommendations given by Stuiver and Polach (1977). The radiocarbon age was calibrated using the OxCal v 4.2.4 software (Bronk Ramsey 2009, 2016) and IntCal20 calibration curves (Reimer et al., 2020). Speleothem radiocarbon date was presented without reservoir correction (dead carbon fraction, $D C F=0$ ), with $D C F$ of $15 \%$ which is generally used for Dinaric secondary carbonates (Horvatinčić et al., 2003), and also with DCF of $12.5 \%$ determined at the Modrič cave near the LCC location (Rudzka et al., 2012), since DCF can vary with location (Srdoč et al., 1986; Krajcar Bronić et al., 1986, 1992; Sironić et al., 2020) and time (Hua et al., 2017; Bajo et al., 2017; Therre et al., 2020). Reservoir corrections were reported according to Soulet et al. (2016):

$$
\begin{aligned}
D C F & =\left(1-F^{14} R_{s-a t m}\right) * 100 \% ; \\
R_{S-a t m} & =-8033 * \operatorname{In}\left(F^{14} R_{s-a t m}\right)
\end{aligned}
$$

where $F^{14} R_{\text {s-atm }}$ is ratio of measured fraction ${ }^{14} \mathrm{C}$ in speleothem and fraction ${ }^{14} \mathrm{C}$ in contemporary atmosphere and $R_{S \text {-atm }}$ is reservoir offset for correction to reservoir effect (reservoir age). Reservoir age is given without rounding.

\section{RESULTS}

\section{Cave Morphology}

The entrance part of the LCC consists of a main channel and several smaller branches. Morphologically, the channel consists of three parts. The first part, $70 \mathrm{~m}$ long, is straight and has a Dinaric orientation (NW-SE). This is followed by two successive bends and a third straight section about $50 \mathrm{~m}$ long. The entire channel runs almost parallel to the hill slope at the surface. The present cave entrance is a $1.6 \times 1 \mathrm{~m}$ door. The entrance was naturally probably much lower but it was artificially slightly modified. The main channel is 6-8 $\mathrm{m}$ high, although in some places it is much higher (over $15 \mathrm{~m}$ ). The width of the channel is generally in the range of 4-7 m. The area cross-sections (Figure 2C) are generally $20-35 \mathrm{~m}^{2}$ but may be larger in some places, especially where the ceiling is higher due to some fractures. The depth of the allogenic sediment in the bottom of the cave channel is not known, so the full dimensions and shapes of the cross sections are not completely known. Three sets of fractures were recorded within the channel, which significantly influence its shape and formation. The first part of the channel is dominated by a set of fractures with Dinaric orientation $\left(\sim 130^{\circ}-310^{\circ}\right)$, the middle part by a set of fractures with meridional orientation $\left(\sim 0^{\circ}-180^{\circ}\right)$, and the last part is the most influential by the set of fractures with orientation of $\sim 100^{\circ}-280^{\circ}$. The host-rock is not stratified, so there is no visible influence of bedding planes on the cave morphology. Numerous speleogens were recorded behind the channel walls: scallops, elongated domes, solution pockets, pendants, wall rills, etc. Flowstones appear only about $80 \mathrm{~m}$ from the entrance, mostly in the form of wide stalagmites and wall flowstones. Due to low temperatures in winter and occurrence of ice on the cave walls, the cryofracture weathering of flowstones is pronounced in this part. The floor in the almost entire length of the channel is built of sediment and in the upper part it is mostly covered by archaeological layer. At the site of the test trench, the channel is slightly larger. It is $12 \mathrm{~m}$ high, $6.6 \mathrm{~m}$ wide, and the cross-sectional area is about $45 \mathrm{~m}^{2}$. This is most likely caused by the intersection of the two sets of fractures (Figure 2D, Supplementary Material S1). The genesis of the whole cave, including this entrance channel, is related to the denudation effect of the sinking waters of the Gračac karst polje. However, its mechanism is not yet completely clear. Morphological traces (cross-sectional shapes and speleogens indicating saturated conditions) of speleogenesis indicate that the channel was formed mainly under saturated conditions. Erosion traces of water flow in the vadose zone were not recorded because, if present, they are located in the lower parts of the channel covered with sediment.

\section{Sediment Characteristics and Facies}

Within the cave sediment infill found in the passage of the LCC, eight intervals were recognized and described. Based on similar lithological and structural features they were grouped into three lithofacies units and the top archaeological layer. A detailed description of the profile and the individual lithofacies units is given in Table 1 and Figure 3A. According to the results of particle size analysis by the sedimentation method (shown by cumulative 
TABLE 1 | Sedimentological field description of DC-SP profile in the Lower Cerovačka Cave with described intervals and lithofacies.

Sediment intervals within the profile DC-SP (cm) Lithology-short field description

DC-SP 1 (0-10) Centimeter to decimeter blocks of limestones and broken speleothems with clayey to silty matrix

DC-SP 2 (10-60) clayey silt to silty clay (carbonate-free sediment) with fragments of speleothems. Numerous findings of well-preserved bones and teeth, belonging to a large vertebrate $(27 \mathrm{~cm}$ from the bottom of the profile)

DC-SP 3 (60-95) clayey silt, probably contains a smaller amount of the sandy component (carbonate-free sediment). Fragments of speleothems are visible in places

DC-SP 4 (95-98) Horizontally oriented speleothem fragments - laterally discontinuous layer covered with a thin layer $(3 \mathrm{~cm})$ of light brown clay that disappears laterally
Lithofacies described within the profile DC-SP

Breakdown facies (Bd) - within the test trench it appears in two stratigraphic horizons which are laterally interrupted. The lower boundary is not visible within the profile DC-SP. Laterally within the test trench, when visible, it is sharp and uneven. Bd facies is built of very poorly sorted angular clasts. Clasts vary in diameter from centimeter to decimeter blocks of limestones and broken speleothems with the chaotic clast supported arrangement (Figures 1A, 3A). Clasts are often colored with black coatings (black coating can be seen also on the flowstone on today's surface of the cave-black coated speleothems). Matrix is clayey to silty. The Bd facies is best visible on the western and southern vertical surfaces of the excavation site, while on the eastern side it is completely absent. The upper boundary of the Bd facies is sharp and uneven. The thickness of the Bd deposits is highly variable laterally. Based on the archaeological photo documentation and field description, the maximum thickness of Bd facies reaches up to $50 \mathrm{~cm}$

Diamicton facies (Di) - represents the filling of a depression formed on the upper surface of the Bd facies, as can be seen, form the disconformity between Bd and Di facies (Figures 3A, 11A). The lower boundary of the facies is partly unclear. The impression is that the sediments of the Di facies in the transition zone intertwine with underlying Bd facies. The same sediments which built the majority of the Di facies also built a matrix of the Bd facies. Di facies is built of clayey silt with no visible gradation through the vertical profile (Figures 4A,B). Although on the described profile these facies appear massive, laterally, unevenly scattered speleothem (seem to be collapsed from the ceiling into the clastic sediment) and limestone fragments can be observed (Figure $\mathbf{3 A}$ ) resulting in unsorted or poorly sorted sediment. There are no clearly arranged sedimentary textures, the larger clasts appear to "float" in the clayey silt. Numerous osteological remains of large vertebrates can be found on this horizon (Figures 3A,B, 11A,D). An unnatural position of the bones is visible on the excavated part of the skeleton. This can be the result of taphonomic processes, but also a sign of re-deposition of the skeleton. The upper boundary of the Di facies represents the lateral continuation of the upper boundary of the Bd facies. It is marked with a thin dashed horizontal zone with fragments of speleothems (Figures 3A, 11C) (platy habitus, perhaps a flowstone deposited on the underlying sediment)

DC-SP 5 (98-108) clayey silt (carbonate-free sediment)

DC-SP 6 (108-130) laminated clayey to sandy silt with intercalations of $\mathrm{mm}$ laminae and thin layers (carbonate-free sediment)

DC-SP 7 (130-170) Homogeneous clayey-silt to silty-clay sediment (carbonate-free sediment)

Slackwater facies (Sw) - Facies of grayish-yellow laminated silt: it is visible on all sides of the test trench. The lower boundary of the Sw facies is sharp and clearly marked. At the bottom, $10 \mathrm{~cm}$ of homogeneous silt sharply turns into an interval of horizontally laminated sediment (mm laminae) (Figures 3A,B). Lamination is marked by vertical alterations of the silty laminae and silty-sandy laminae. Occasionally thin layers occurred (up to $1 \mathrm{~cm}$ ). The thickness of the laminated interval varies laterally - the laminated interval is thinnest at about $1 \mathrm{~m}$ from the side of the cave wall with laminae and layers dipping toward the middle of the cave channel. Therefore, lamination partly follows the inherited morphology in the underlaying homogeneous silt and it showing a channel-like form with a maximum height of up to $10 \mathrm{~cm}$, but erosional discordance has not been observed. Laminae follow the shape of the "channel". Toward the top of the profile, there is a transition toward the zone with wavy lamination (probably a postsedimentary deformation of the sediment-convolution). Small cracks with vertical displacement between layers were also observed (micro faults). The increase in the amount of sand in the laminated horizon is visible from the particle size distribution curves (samples DC-SP 105 to DC-SP 135, Figure 4B). The upper $40 \mathrm{~cm}$ of the Sw facies represent silty massive sediment with a decreased amount of sand (Figures 4B 11B) and show a finning upwards trend. The upper boundary is marked with uneven and sharp disconformity to the late Bronze age and Modern period archaeological strata (Figure 11A)

DC-SP 8 (170-195) archaeological strata with pottery fragments. lapodes, late Bronze age

granulometric curves, Figure 4A) it can be seen that all described intervals consist of clayey silt to silt with a small amount of very fine sand particles ( $<9 \%$ of sand). According to Trask's sorting coefficient $\left(\mathrm{S}_{0}\right)$, all samples show poor to very poor sorting (1.802-3.067), while the asymmetry coefficient $(\mathrm{Sk}<1)$ shows that grains smaller than the median (average Md value is 0.0154 ) predominate in the samples. Samples DC-SP 2, 3 and 5 are classified as very poorly sorted clayey silt, while samples DC-SP 6 and 7 are classified as poorly sorted silt. Furthermore, the results of the high-resolution particle size analysis using the laser diffractometer show a decrease in the amount of the clay-sized fraction from bottom to top of the section (Figure 4B), the trend 


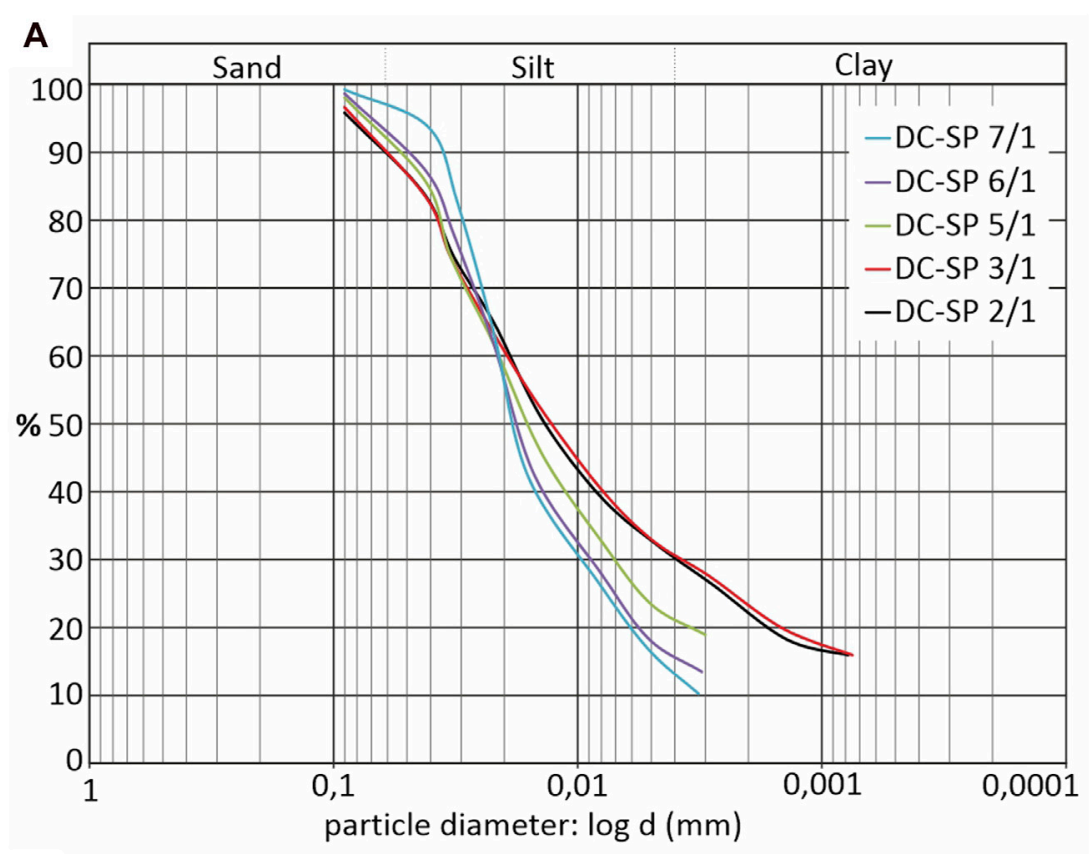

B

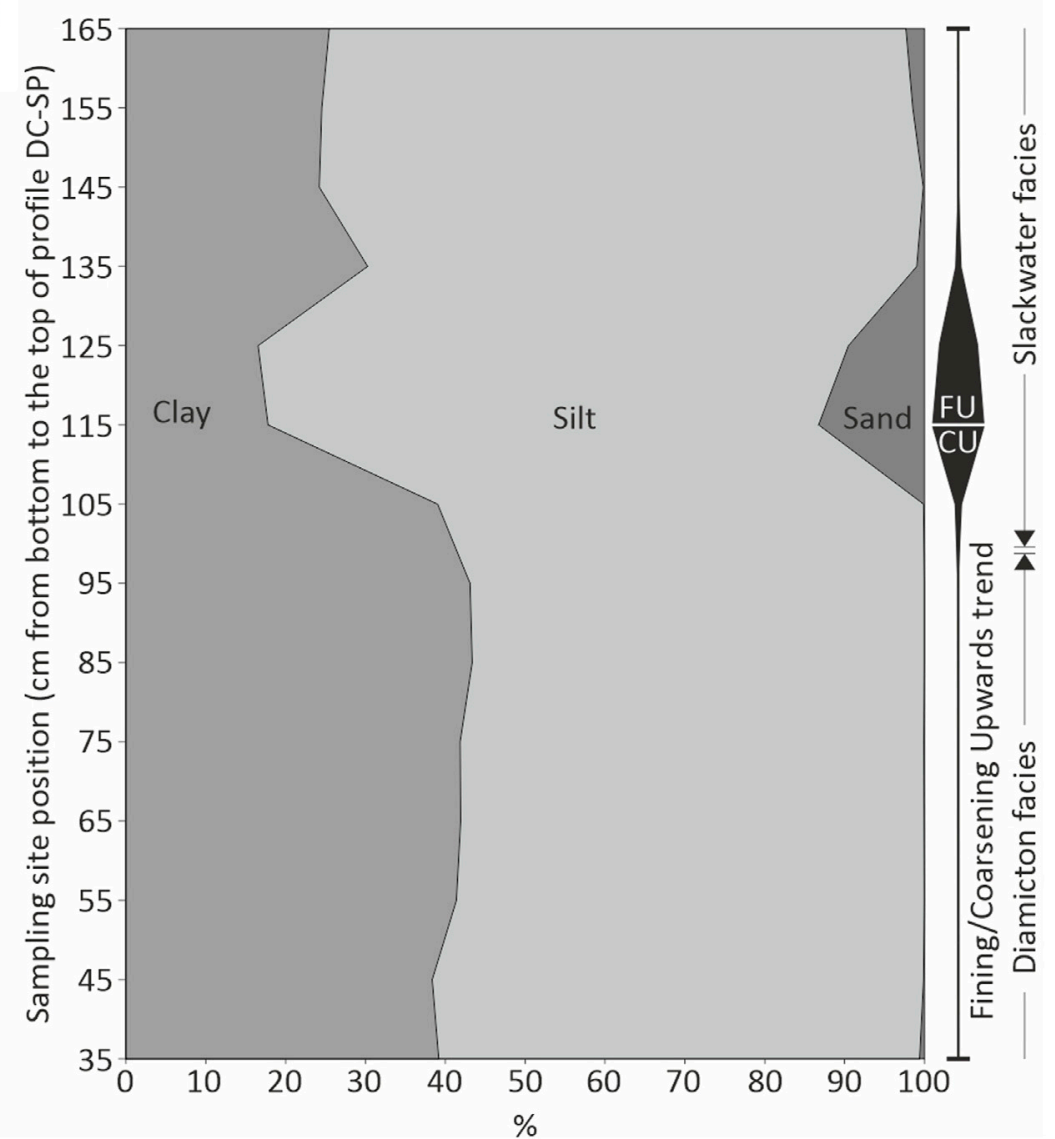

FIGURE 4 | Granulometric composition of samples from the profile DC-SP. (A) Granulometric analysis by sedimentation method: cumulative granulometric curves, (B) distribution curves of individual fractions (clay, silt, and sand) through the investigated profile. 
TABLE 2 | Mineral composition of silty cave sediment from profile DC-SP in the Lower Cerovačka Cave.

\begin{tabular}{|c|c|c|c|c|c|c|c|c|c|c|}
\hline \multicolumn{11}{|c|}{ Light mineral fraction composition (fraction $0.09-0.16 \mathrm{~mm}$ ) shown in \% } \\
\hline \multirow{2}{*}{$\begin{array}{l}\text { Sample } \\
\text { DC-SP } 2\end{array}$} & \multicolumn{2}{|c|}{$\begin{array}{c}\text { Quartz } \\
\text { (monocrystalline) }\end{array}$} & \multicolumn{2}{|c|}{ Feldspars (kfs+PI) } & \multicolumn{4}{|c|}{ Lithic particles (chert and other) } & \multicolumn{2}{|c|}{ Muscovite } \\
\hline & \multicolumn{2}{|c|}{92} & \multicolumn{2}{|c|}{2} & \multicolumn{4}{|c|}{6} & \\
\hline DC-SP 3 & \multicolumn{2}{|c|}{92} & \multicolumn{2}{|c|}{3} & \multicolumn{4}{|c|}{5} & \multicolumn{2}{|c|}{+} \\
\hline DC-SP 5 & \multicolumn{2}{|c|}{88} & \multicolumn{2}{|c|}{8} & \multicolumn{4}{|c|}{4} & & \\
\hline DC-SP 6 & \multicolumn{2}{|c|}{87} & \multicolumn{2}{|c|}{9} & \multicolumn{4}{|c|}{4} & \multirow{2}{*}{\multicolumn{2}{|c|}{+}} \\
\hline DC-SP 7 & \multicolumn{2}{|c|}{84} & \multicolumn{2}{|c|}{8} & \multicolumn{4}{|c|}{8} & & \\
\hline \multicolumn{11}{|c|}{ XRPD analysis (bulk samples) shown in \% } \\
\hline & Qtz & $\mathbf{P I}$ & $14 \AA$ & $10 \AA$ & $9 \AA$ & $7 \AA$ & Gbs & Hem & HA & Clays \\
\hline DC-SP 1 bone & & & & & & & & & 100 & \\
\hline DC-SP 1 & 12 & & + & + & + & & & & 39 & 49 \\
\hline DC-SP 2 & 35 & & + & + & + & + & $?$ & * & & 65 \\
\hline DC-SP 3 & 36 & & + & + & + & + & * & * & & 64 \\
\hline DC-SP 4/2 & 30 & 6 & + & + & & + & $?$ & $?$ & & 64 \\
\hline DC-SP 5 & 31 & 4 & + & + & & + & * & $?$ & & 65 \\
\hline DC-SP 6 & 32 & 7 & + & + & & + & $?$ & $?$ & & 61 \\
\hline DC-SP 7 & 34 & 6 & + & + & & + & & $?$ & & 60 \\
\hline
\end{tabular}

XRPD analysis (fraction $<2 \mu \mathrm{m}$ ) shown by the relative abundance

\begin{tabular}{|c|c|c|c|c|c|c|c|c|c|c|}
\hline & L.c. Vrm & Vrm & III/Ms & Tlc-Prl & KIn & $K \ln D$ & Chl & Qtz & Chl-V & I-S \\
\hline DC-SP 2 & * & $x X$ & $x$ & * & $x$ & * & $x X$ & - & $x$ & * \\
\hline DC-SP 3 & * & $X X$ & $x$ & * & $X X$ & * & $x$ & * & $x$ & \\
\hline DC-SP 4/2 & $x$ & $x$ & $x$ & * & $X X$ & & $x$ & * & $x$ & \\
\hline DC-SP 5 & * & $X X$ & $x$ & * & $x X$ & * & $x$ & * & $x$ & \\
\hline DC-SP 6 & * & $x$ & $x$ & & $x X$ & * & $x$ & * & $x$ & * \\
\hline DC-SP 7 & $x$ & $x$ & $x$ & & $X X$ & * & $x$ & * & $x$ & * \\
\hline
\end{tabular}

Data is obtained by modal analysis of Light mineral fraction (performed on fraction 0.09-0.16 mm), and by Quantitative XRPD analysis. Quantitative mineral composition of bulk samples and semi-quantitative mineral composition of the <2 $\mu \mathrm{m}$ fractionis are shown. Abbreviation codes: Qtz-quartz, PI-plagioclase, Gbs-gibbsite, Hem-hematite, HA-hydroxylapatite, 14, 10, 9, $7 \AA$-type of clay minerals present in bulk sample marked with +, ?-mineral is probably present in the sample but cannot be confirmed with certainty because of low content and/or overlapping of diffraction maximums. L.c. Vrm-Low-charge vermiculite or high-charge smectite, Vrm-vermiculite, III/Ms -illite/muscovite, Tlc-Prl-talc-pyrophillite group, KIn = Kaolinite which does not intercalate with DMSO, KInD-kaolinite which forms intercalation compounds with DMSO, ChI-chlorite, Chl-V-chlorite-vermiculite mixed-layerd clay mineral, I-S-illite-smectite mixed-layerd clay mineral, XXX-dominant (>50\%), XX-abundant (20-50\%), X-subordinate (1-20\%), *-traces $(<1 \%)$.

comparable to the results of areometric particle size analysis (Figure 4A).

\section{Mineralogical Composition of the Sediment}

The results of the modal analysis of the sediment samples are given in Table 2. Within all samples the LMF predominates, represented by grains of monocrystalline quartz (84-92\%) which is mostly represented by angular and slightly rounded grains of uniform and undulose extinction. In addition to this dominant group, euhedral quartz grains can be found (Figure 5A). Sporadic occurrences of well-rounded and spherical quartz grains were recorded, as well. The amount of rock fragments ranges from 4 to $8 \%$. Among them, the most common are chert particles. Rare tuffitic particles were found, as well as schist rock fragments. Feldspars are represented mainly in the form of potassium feldspars, and their total amount is up to $9 \%$. Feldspars are most often anhedral (Figure 5B) to subhedral. Mica (muscovite) appears only sporadically $(<1 \%)$ in the form of transparent plates with a rounded outline (Figure 5C). The LMF is quite uniform throughout the profile (Table 2). A slight decrease in the number of quartz grains toward the top of the profile was observed, and in connection with that, a slight increase in the number of feldspars and lithic particles. The mineral composition of all analyzed samples is uniform. Among the HMF, the amount of opaque minerals is high, about $90 \%$. Completely opaque black grains, often well rounded, are observed. Chromite grains, slightly reddish-brown colored, are present in all analyzed samples and in some samples pyrite (Figure 5D). The THM are very sparse in the samples. Among the THM, the pyroxene predominates. They appear in the form of anhedral to stubby prismatic grains, are green in color and the typical "hacksaw" terminations are often visible (Figures 5F,G). According to the extinction angle, they are classified in the group of clinopyroxene. The second most common translucent heavy mineral is zircon. Zircons, mainly short-prismatic or anhedral (slightly rounded) are present in all samples. Euhedral grains are rare (Figure 5G). Tourmaline is present in roughly the same proportion as zircon. It appears in the form of subhedral grains. It is rounded in some places. Pleochroism in brown to greenish color is visible in places. Other observed varieties belong to a group of hemimorphic grains with multicolored poles (Figures $\mathbf{5 E}, \mathbf{H})$. Rutile is rare but still present in all samples, appearing in rounded forms with a slightly prismatic habitus. Their color is usually reddish-brown or dark red. Garnets are rare, occur in the form of weakly rounded grains or angular grains/shards with 

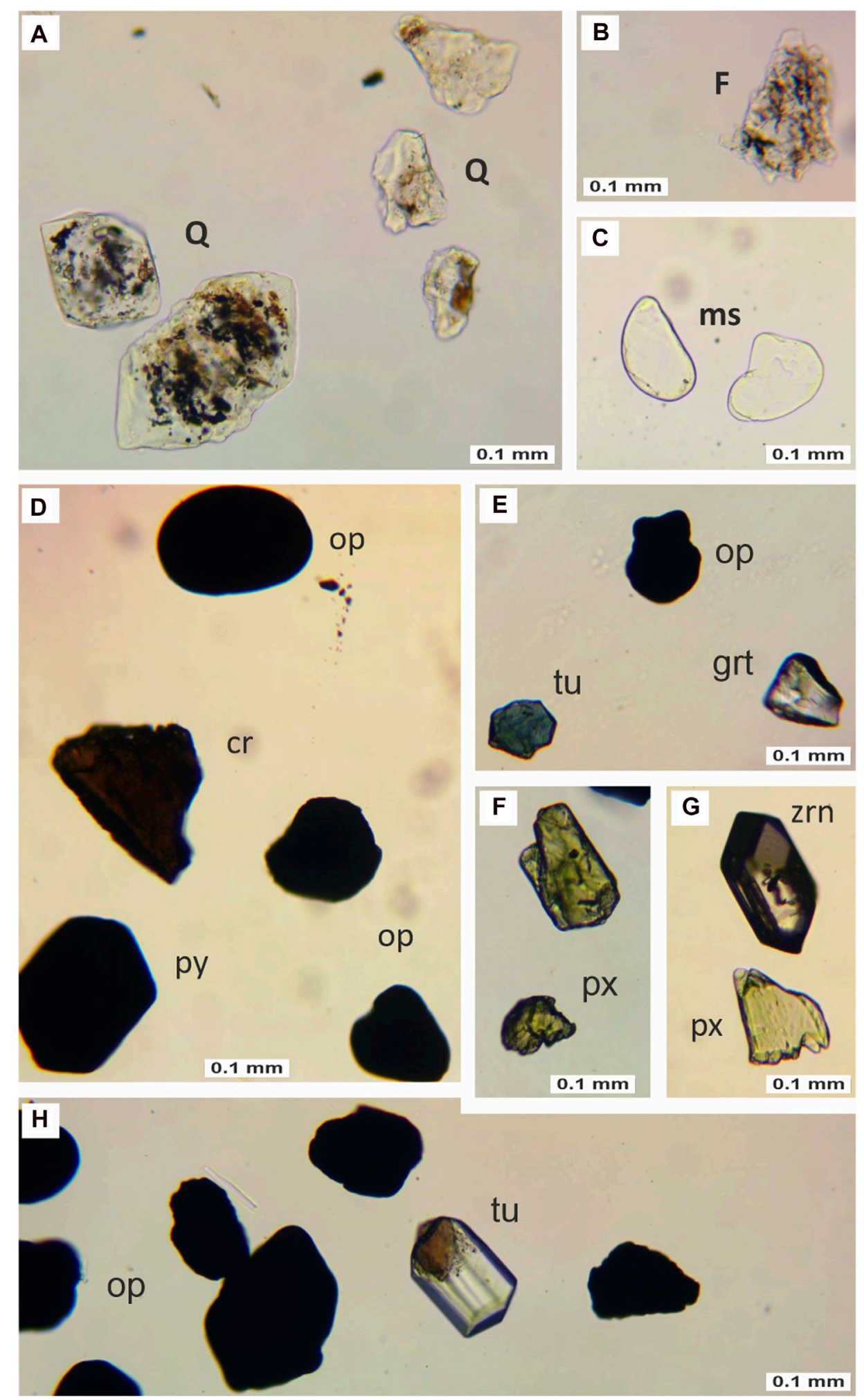

FIGURE 5 | Overview of selected mineral grains from the light and heavy mineral fraction of the DC-SP profile (photo without analyzer). (A) Weakly rounded allotriomorphic and hypidiomorphic quartz grains (Q) from sample DC-SP 2, (B) Feldspar (F) from sample DC-SP 2, (C) muscovite grains (ms) from sample DC-SP 7, (D) rounded opaque minerals (op), chromite (cr), and pyrite (py) from sample DC-SP 2, (E) opaque minerals (op), tourmaline (tu), and garnet (grt) from sample DC-SP 6, (F) pyroxenes (px) from sample DC-SP 6, (G) zircon (zrn), and pyroxene (px) from sample DC-SP 2, and (H) opaque minerals (op) and tourmaline (tu) from sample DCSP 3. 
sharp edges. Colorless garnets predominate. Slightly pink garnets are also present (Figure 5E). Among other THM, grains from the epidote-zoisite group rarely occur. The epidote is greenish, semi-rounded, in the form of irregular grains while mineral grains classified as zoisite/clinozoisite look fresh and show an anomalous blue interference color. Rare occurrences of biotite and greenish anhedral amphiboles are also present.

The results of the XRPD method are shown in Table 2. Sample DC-SP 1 is extremely heterogenous. It consists of bone fragments, and sandy silt size sediments. The analysis was performed on both parts. Sediment sample DC-SP 1 (silt), in addition to clay minerals, contains a significant amount of hydroxylapatite (HA) and quartz (Table 2). Quantities of fractions $<2 \mu \mathrm{m}$ were too small for clay analysis, so the analysis was performed on a fraction $<0.063 \mathrm{~mm}$. In that fraction quartz, vermiculite, illite/muscovite, talc-pyrophyllite, kaolinite and a small amount of chlorite are present. Bone fragment sample consists only of HA. The main mineral phases in all other analyzed samples are clay minerals and quartz (Table 2). Samples DC-SP 4 to DC-SP 7 contain a smaller amount of plagioclase. Some of the samples (Table 2) contain a very small amount of gibbsite and hematite, but due to the low content cannot be confirmed with certainty in all samples. Mineral composition of $<2 \mu \mathrm{m}$ fraction of all analyzed samples is similar. In the analyzed samples, among clay minerals, vermiculite, illite/muscovite, kaolinite, and a lesser amount of chlorite and chlorite-vermiculite regularly appear. In some samples, small quantities of low-charge vermiculite or highcharge smectite, talc-pyrophyllite, kaolinite which forms intercalation compounds with DMSO and illite-smectite are also present. Samples DC-SP 3 and DC-SP 5 probably contain secondary chlorite (the $14 \AA$ diffraction maximum disappeared after heating to $550^{\circ} \mathrm{C}$ ).

\section{Palynofacies}

Palynofacies of all studied samples beside the oldest one (DC-SP 1) are dominated by phytoclasts. Sporomorphs occur in a small amount and therefore there is no standard palynological diagram. Instead of that, only organic matter abundance is presented in the diagram (Figure 6). In the oldest analyzed sample, DC-SP 1, the palynofacies is dominated by bacterial amorphous organic matter (AOM) particles (Figure 7A), and non-opaque phytoclasts, mostly amorphous particles, which indicate an increased input of terrigenous material. Only a few Pinaceae pollen (Figure 7C) and Fungi spores occur. Microscopic charcoal remains (around 100 microns in size; Figure $7 \mathbf{B}$ ) point to the influence of fire (Whitlock and Larsen, 2002). Palynofacies from the sample DCSP 2 is dominated by opaque phytoclasts, mostly corroded charcoal, while non-opaque phytoclasts decreased. Sporomorphs from conifer Pinaceae (Figure 7D) family as well as herbs of Asteraceae (Figure 7D) and Cichoriaceae family (Figure 7E) dominate in the same ratio $(6 \%)$. They point to a cold and dry climate, probably to a glacial stage. In sample DC-SP 7 palynofacies is still dominated by the opaque phytoclasts, mostly corroded charcoal. Beside phytoclasts there are a lot of particles resembling cyanobacteria, maybe degraded cyanobacteria (Figures 7F,G) that lived in the cave. Palynofacies from the youngest sample DC-SP 8 is dominated by the phytoclasts, mostly non-opaque phytoclasts-brown wood and amorphous particles. Rare findings of the palynomorph Pseudoschizaea (Figure 7I), probably related to Zygnemataceae, indicate the runoff due to periods of enhanced soil erosion outside the cave (Leroy et al., 2007). The presence of spores from the genus Glomus suggests erosion from a forested upstream slope (van Geel, 2001), possibly due to fires, themselves evidenced by an increase in microcharcoal particles. Aquatic pollen (Typha) and grasses (Graminae) were also present in the similar ratio (ca. 3\%). At the same time rare Polygonum persicaria (Figure $\mathbf{7 H}$ ) points to anthropogenic influence.

\section{Paleontological and Taphonomic Analysis}

The vertebrate remains from the Pleistocene deposits of the test trench (specifically 873 fragments) were recovered at a depth of $\sim 1.2 \mathrm{~m}$, within a $30 \mathrm{~cm}$ thick layer (Figure 3A). Of these, 230 bones and teeth are identified to the genus Ursus (26.4\%). The vertebrate remains are therefore documented and presented within Figure 8. Based on morphological and metrical characteristics, all bear remains from LCC are attributed to cave bear (U. spelaeus), making this species the only mammalian taxon identified within the analyzed faunal assemblage from Pleistocene deposits. The vast majority of the remains, however, remained taxonomically undetermined. Based on their relative size and robustness, many of these remains could also come from a cave bear. However, given the mention of rare findings of other large carnivores and herbivores in previous studies (Malez, 1965b; Paunović et al., 1999), this assumption should be considered with caution and the possibility of the existence of other taxa in this assemblage should not be ruled out. Although most of the remains could not be aged precisely, information of the relative age at death shows predominance of adult bears (81.7\%), while the rest belongs to juveniles (Figure 8). A single bone is attributed to a fetal or newborn animal.

In order to study the body part representation of bears in the LCC, data for both cave bear and taxonomically indeterminate remains of the similar body size are combined. All major parts of the body are present (Figure 8) suggesting deposition of complete bear carcasses within the cave. However, a closer examination of the differential representation of different body parts revealed the following: the most abundant class are trunk elements (32.2\%), closely followed by the elements of the head (teeth included; $29.1 \%$ ) and feet bones (25.2\%). Relative to them, larger bones of the appendicular skeleton are under-represented within the analyzed assemblage. Thus, the upper elements of the fore limbs (scapula, humerus, radius, ulna) and hind limbs (pelvis, femur, tibia, fibula) are represented by only 6.1 and $7.4 \%$, respectively.

With the exception of a few more complete bones, the skeletal material is fragmented. Recent breaks are present but most breakages are dry and attributable to natural processes typical of cave environment (e.g., trampling by other animals, sediment pressure). Looking at the bone surface modifications the material is relatively well preserved. The average bone color varies between pale white to yellowish white. Just a few fragments display small areas of dark brownish coloration, suggesting light staining probably due to exposure to minerals in the sediment. Besides fragmentation, the most common taphonomic modification is very light weathering (fine line fractures and spalling of bone surface), while chemical etching is evidenced on several 


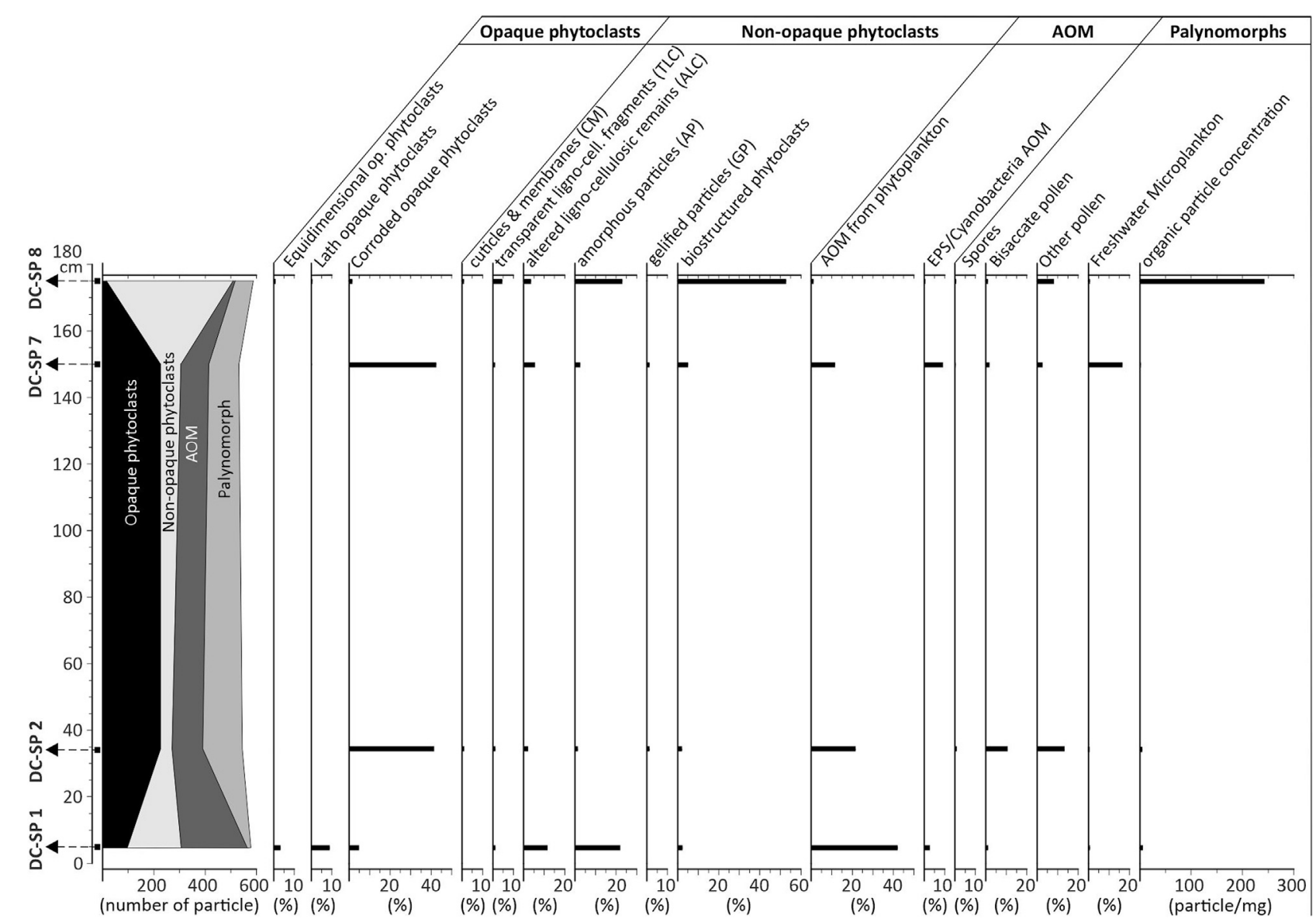

FIGURE 6 | Organic matter (OM) percentage abundance diagram for the DC-SP profile in the Lower Cerovačka Cave. Diagram was made with the Tilia software (Grimm, 1991).

fragments. In addition, only a few bones were gnawed by large carnivores (e.g., cave lion or hyena) and there is no evidence of modification by hominins.

\section{Luminescence Dating}

Using the rejection criteria determined in dose recovery experiments, 43 equivalent dose values were accepted for the $\mathrm{IR}_{50}$ signal, and 33 for the $\mathrm{PIRIR}_{225}$ signal, respectively. Dose distributions for both signals are positively skewed and show overdispersion values of $56 \pm 7 \%\left(\mathrm{IR}_{50}\right)$ and $42 \pm 7 \%\left(\mathrm{pIRIR}_{225}\right)$, which in combination can be interpreted as an indication for incomplete bleaching being significant in the sample. Therefore, average equivalent doses for both signals were calculated using a bootstrapped three-parameter minimum age model (Galbraith et al., 1999; Cunningham and Wallinga, 2012), with sigma $0.3 \pm 0.2$ as a threshold value, based on the overdispersion values from dose recovery experiments and assigned with an uncertainty to account for the lack of a well-bleached natural reference sample. The g-values of $5.6 \pm 0.8$ for the $\mathrm{IR}_{50}$ and $0.6 \pm 0.9$ for the pIRIR $_{225}$ signal were obtained after fading corrections. Fading correction was conducted using the approach of Huntley and Lamothe (2001) and calculated using the R-Luminescence package of Kreutzer et al. (2012). Equivalent dose values and resulting ages as well as all luminescence results are summarized in Table 3.

The different characteristics of the two luminescence signals measured with the pIRIR $_{225}$ dose protocol can be used to assess the reliability of the determined ages. The $\mathrm{IR}_{50}$ and $\mathrm{PIRIR}_{225}$ signals are known to exhibit different fading rates, as was confirmed by the fading measurements in this study, and different bleaching rates, with the $\mathrm{IR}_{50}$ signal bleaching much faster than the pIRIR 225 signal (e.g., Murray et al., 2012; Bickel et al., 2015a, 2015b). If incomplete bleaching is significant in a sample, the success of the correction of the effect of incomplete bleaching using the statistical approach of the bootstrapped MAM can be assessed by comparing the fading corrected ages for both signals. If the apparent age of the $\mathrm{IR}_{50}$ is significantly younger than that of the pIRIR 225 signal, incomplete bleaching was not successfully corrected for. If, however, the fading corrected ages for the two signals are in agreement within error limits, like is the case here, this is a strong argument for a successful correction of the effects of incomplete bleaching. Although fading correction was applied also for the $\operatorname{PIRIR}_{225}$ signal for comparative reasons, the fading rate is negligible 

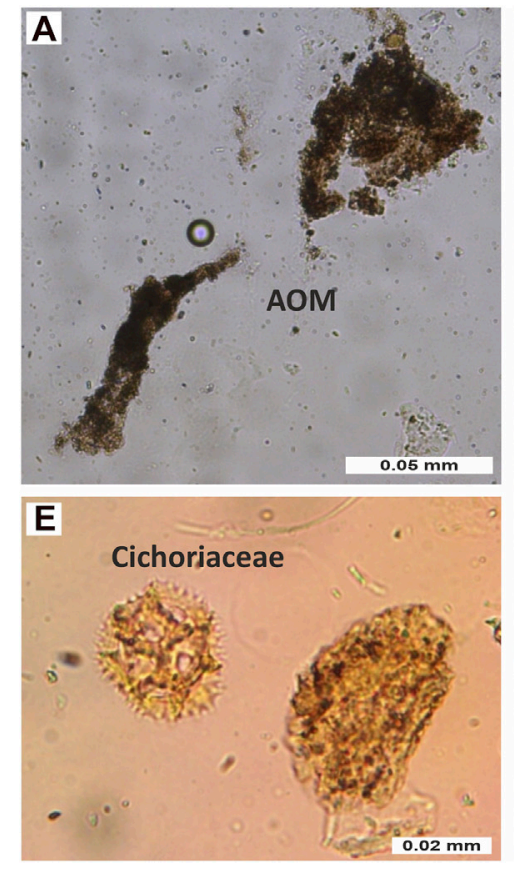
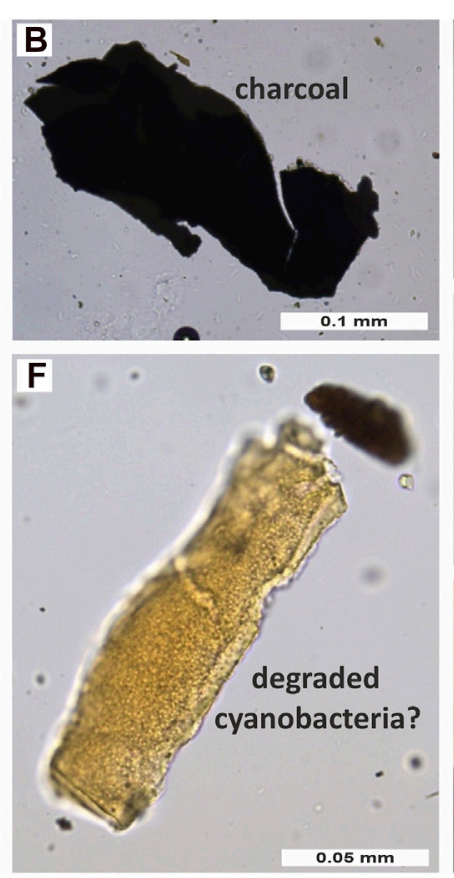
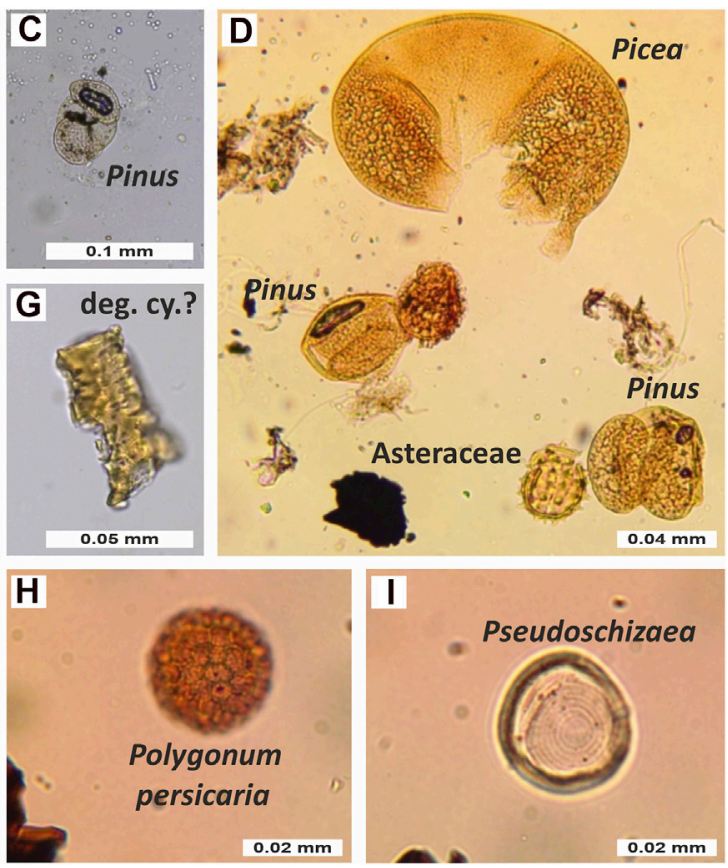

FIGURE 7 | Palynofacies from the profile DC-SP in the Lower Cerovačka Cave (A,B) DC-SP 1, (C,D) DC-SP 2, (E,F) DC-SP 7, and (G,H) DC-SP 8.

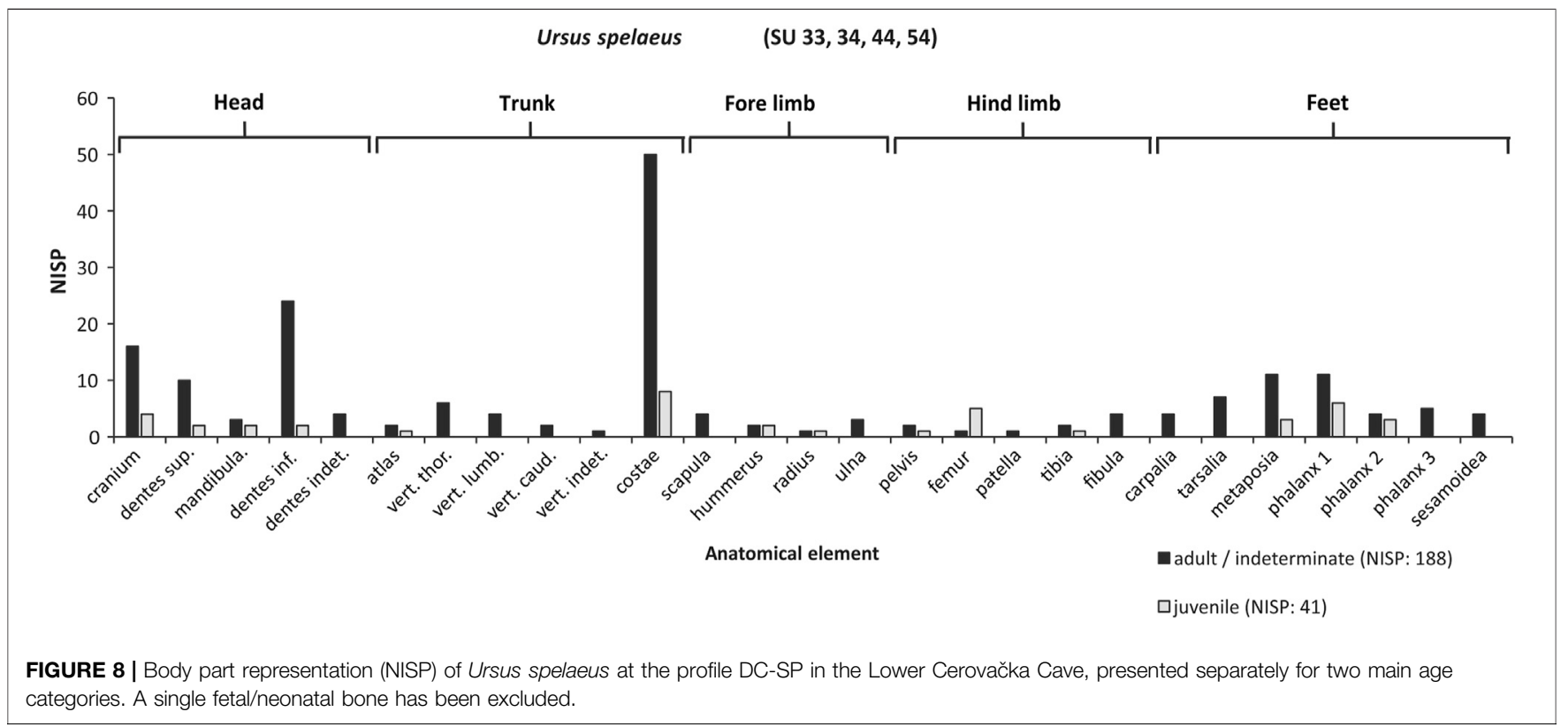

within error and because of that the pIRIR $_{225}$ based age not corrected for fading of $53.7 \pm 6.9 \mathrm{ka}$ can be regarded as the most reliable depositional age for the sample (marked in bold in Table 3). In addition, it is important to note that the luminescence age is in stratigraphic order with the radiocarbon age obtained from a flowstone sample (Chapter 4.6.2), further corroborating the high reliability of the age determination.

\section{Radiocarbon Dating}

The speleothem sample (Z-7352, graphite number A2160 (RBI), ID number UGAMS\# 49576 (CAIS) - Figures 9A-C) had $F^{14} \mathrm{C}=$ $0.1148 \pm 0.0006(17,390 \pm 40 \mathrm{BP})$ and $\delta^{13} \mathrm{C}-5.3 \pm 0.1 \%$. $F^{14} \mathrm{C}$ and radiocarbon dates without and with $D C F$ of 12.5 and $15 \%$, along with their calibrated dates are presented in Table 4. Compared calibration curves for both 12.5 and 15\% DCF and both for using the reservoir function in $\mathrm{OxCal}$ and calibrating raw ${ }^{14} \mathrm{C}$ dates are 


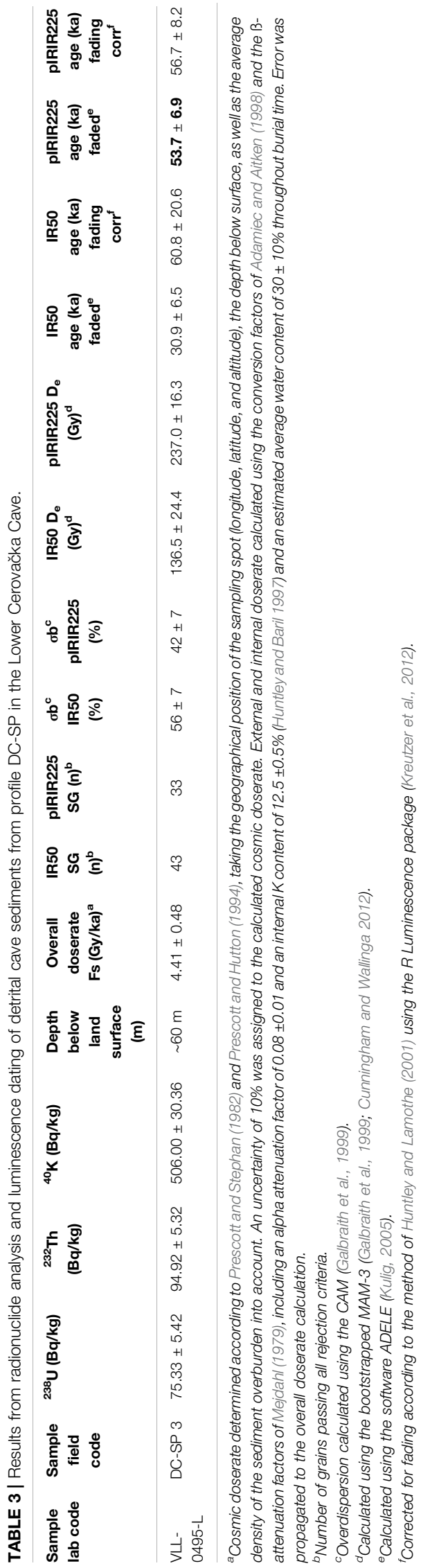

presented in Figure 9D. Here should be pointed out that there is a large difference between conventional radiocarbon dated (expressed as BP) and calibrated calendar dates (expressed as cal $\mathrm{AD}$ and $\mathrm{cal} \mathrm{BC}$ ) in this part of the radiocarbon calibration curve, resulting in difference of about 2,500 years between the conventional and calibrated age. The true age of material with the obtained age of $16 \mathrm{ka} \mathrm{BP}$ is therefore $\sim 19.5 \mathrm{ka}$ old (Table 4).

\section{DISCUSSION}

\section{Mineral Composition and Provenance of Cave Sediments}

The investigated sediments represent the clastic filling of cave channels. Earlier research assumed that the clastic filling of cave channels is an accumulation of in situ products of weathering of the host rock (Malez, 1965). According to mineralogical analysis presented within this paper the cave sediment is mainly allochthonous clastic detritus but a part of it is autochthonous chemogenic and collapse material. The overall mixture of cave detrital sediments depends greatly on the weathering products in the source area, transported and deposited by episodic events in different facies types (depending on flow dynamics) inside the cave (Georgiadis et al., 2019). Therefore, our results are compared to the geological units in the river Otuča catchment area (Figures 1B,C).

The results of the LMF and XRD analysis (Table 2) shows that the main components of the analyzed cave sediments are quartz and clay minerals. The sample DC-SP 1 additionally contains bone fragments and significant amounts of hydroxyapatite (HA) (Table 2). HA is the main constituent of mammalian bones and teeth and is often recognized within cave sediments, like e.g., in the Modrič Cave (Miko et al., 2001). Also, the relationship between the habitation of bats and HA formation in caves has been found in limestone caves worldwide (Hill and Forti, 1997). HA is usually formed as a crust that coats speleothems and bedrock substrate surfaces within or near bat habitats, while powdery forms of HA could be found under bat guano deposits (Chang et al., 2010 and references therein). Hence, it is possible that beside the tiny bone fragments in the fine-grained part of the sample DC-SP 1, a part of the HA may also have originated from the in situ bat guano, as indicated by the dark color of the sediment. In samples DC-SP 4 to DC-SP 7 small amount of plagioclase are also present (Table 2). Their preservation in the samples and the absence of gibbsite and hematite indicates that these samples were subjected to less intensive pre-burial weathering compared to samples DC-SP 2 and DC-SP 3. The clay minerals contained in the analyzed cave sediments (Table 2) are similar in composition to the Terra Rossa type paleosols developed on the carbonate rock in the Adriatic region (Durn et al., 2007, 2018). In the wider Mediterranean area, the mineral composition of Terra Rossa type soils and palaeosols may be very variable (Durn, 2003). This variable composition is a consequence of the polygenetic nature of Terra Rossa which can form exclusively from the insoluble residue of limestone and dolomite but much more often encompasses a range of parent materials that arrived on the carbonate terrain by different 


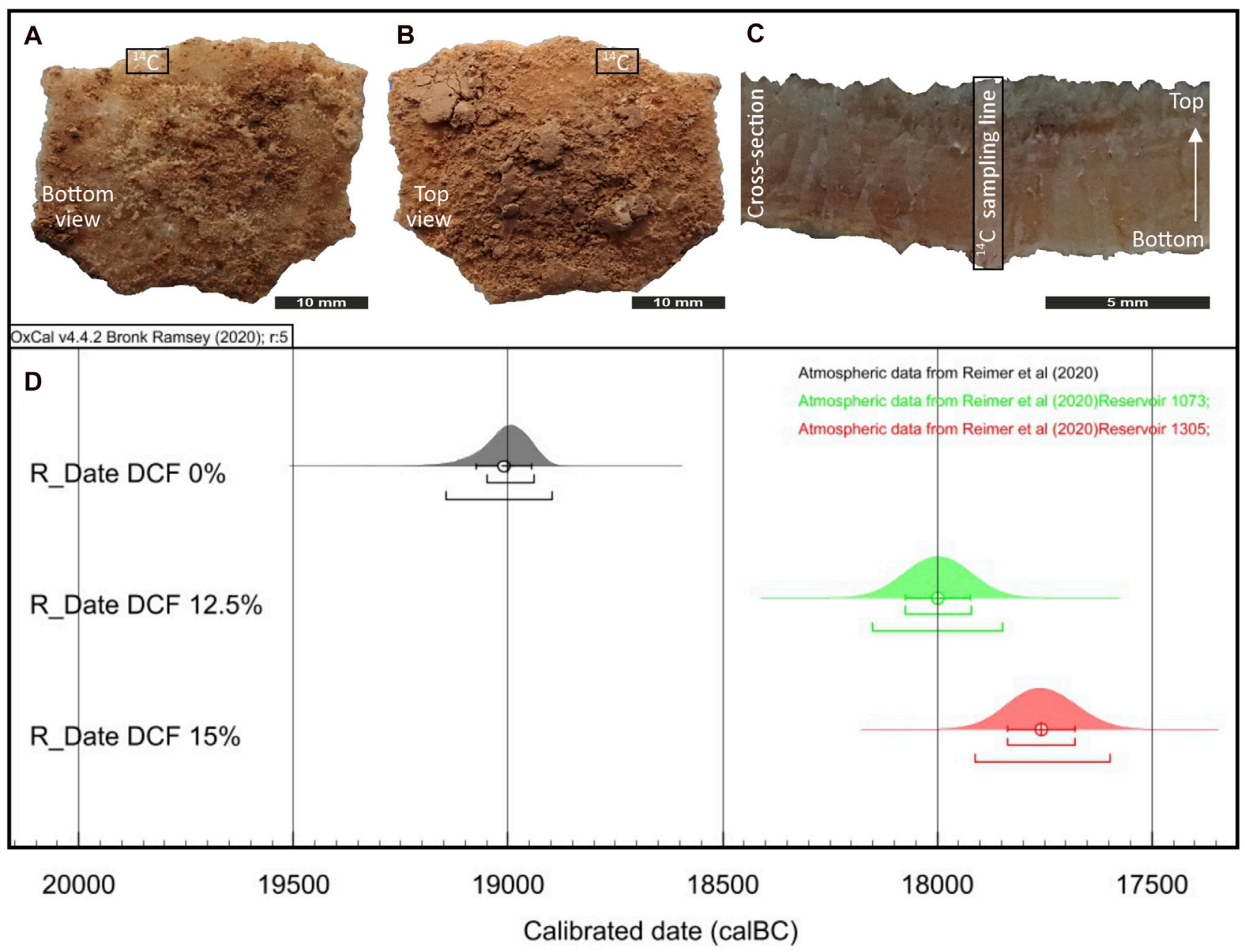

FIGURE 9 | Sampled flowstone $\left({ }^{14} \mathrm{C}\right)$ from the DC-SP profile in the Lower Cerovačka Cave (A) Bottom view, (B) top view, (C) cross-section with indicated sampling line, (D) calibration curves for ${ }^{14} \mathrm{C}$ date without DCF correction (in gray), and for $12.5 \%$ ("Reservoir 1,073," in green) and 15\% ("Reservoir 1,305," in red) DCF.

TABLE $4 \mid F^{14} \mathrm{C}$ and radiocarbon dates and calibrated dates for dead carbon fraction of 0, 12.5 and $15 \%, R_{S \text {-atm }}-$ reservoir offset for correction to reservoir effect using the OxCal v 4.2.4 software (Bronk Ramsey 2009, 2016).

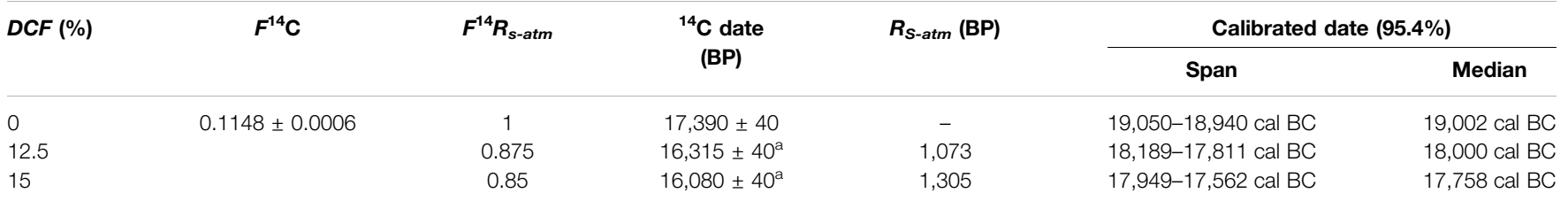

${ }^{a}$ Dates presented only for orientation, not used directly in the calibration curve.

Radiocarbon dates were calibrated using IntCal20 calibration curve (Reimer et al., 2020) and calibrated date spans are given with 95.4\% confidence ( $\mathrm{k}=2$ ).

transport mechanisms (Durn, 2003). Thus, in Istrian Terra Rossa, the dominant mineral phases in the clay fraction are kaolinite, illitic material, Fe-oxides and XRD amorphous inorganic compounds, while vermiculite, low-charge-vermiculite or highcharge smectite, chlorite, mixed-layer clay minerals and quartz are present in smaller quantities (Durn, 2003). Terra Rossa soils from Western Herzegovina have a similar composition where the dominant mineral phases in the clay minerals fraction are kaolinite, Fe-oxides and XRD amorphous inorganic compounds, while vermiculite, smectite, illitic material, chlorite-vermiculite and quartz are present in a subordinate amount (Durn et al., 2014). However, even though cave sediments show similarities to Terra Rossa type soils, they cannot be classified as soils (Zupan Hajna et al., 2020). Cave 
sediments reveal a good, multi-proxy record of cave and surface environmental conditions in the time of their deposition (Bosák, 2002). Therefore, the red clayey-silty sediments found in the LCC can, to some extent, be considered as redeposited Terra Rossa. Despite the similarities, cave sediments appear to have suffered less advanced stages of weathering compared to Terra Rossa. Iacoviello and Martini (2012) came to the same conclusion comparing the clay mineral composition of cave sediments and Terra Rossa soils in the karst massif of Montagnola Senese in Italy. The source area of the investigated sediment could be in the Gračac karst polje in the close vicinity of the entrance to the LCC. In the catchment area of the Otuča river (Figure 1B), approximately $3.5 \mathrm{~km}$ upstream of today's ponors close to the cave entrance, the river flows through the area covered with Terra Rossa type sediment, as can be seen from the geological map (Figure 1C, unit 10; Ivanović et al., 1973). Beside kaolinite, vermiculite, illite/muscovite, chlorite and mixlayered clay minerals, samples DC-SP 2 to DC-SP 6 contain minerals from the talc-pyrophillite group (Table 2). Talcpyrophyllite usually occurs as a minor component in soils, which could be inherited from the parent rock, but they can also form as a result of weathering processes (Weaver, 1989). According to Velde and Meunier (2010) talc can be formed directly from pyroxenes. Other secondary minerals that can be formed from pyroxene are vermiculite, smectite, kaolinite or hematite. The analyzed samples contain a small amount of pyroxene group minerals (Table 2) which could have been the parent material for the talc-pyrophyllite group of minerals. Hematite is present only in traces (Table 2), very likely derived from the Terra Rossa. The mineral assemblage determined by the XRD within the analyzed DC-SP samples is comparable to detrital cave sediments within Dinaric karst (Bosák et al., 2012; Zupan Hajna et al., 2021), and e.g., cave sediments from northwestern Oltenia in Romania (Ghenciu, 2017). When comparing cave sediment compositions, it should be noted that the composition of these sediments depends on the clastic source rocks, and factors such as weathering and/or pedogenesis.

To answer the question about the clastic source rocks and source areas, results of LMF and HMF analysis (Table 2; Figure 5) were compared to the main lithological units in today's catchment area of the Otuča river and Gračac karst polje (Figures 1B,C). Underground passages of the LCC are developed in the Tertiary carbonate breccia host rock (Ivanović et al., 1973) (Figure 1C, unit 8), known as Jelar breccia (Bahun, 1963,1974 ) which is locally composed of various lithic fragments, most commonly related to the lithological composition of underlying rocks. Therefore, the breccia is mainly composed of lithic fragments of Jurassic, Cretaceous, and younger Paleogene carbonate rocks (Ivanović et al., 1976). In the investigated sediment, it was not possible to recognize this carbonate source area, except within the clearly in situ formed $\mathrm{Bd}$ facies which contains angular boulders of the host rock (Figure 11A). However, in most of the sediment, the siliciclastic detritus predominates (Table 2) which points to the allochthonous origin of the detritus. According to the results of the HMF and LMF analysis (Figure 5; Table 2) it can be concluded that the source of the clastic detritus is connected to the wider river Otuča catchment area. Downstream from the source, river Otuča flows through the upper Carboniferous deposits (Šušnjar et al., 1973) (Figure 1C, unit 1), mostly clayey shales and sandstones, accompanied by conglomerates. In the composition of the clayey shales quartz, muscovite, chlorite, plagioclase, kaolinite, organic substance, and pyrite can be found. In the layered, well-sorted, and fine-grained sandstones the detritus is composed mainly of quartz, muscovite, chlorite, lithic fragments, and a small amount of plagioclase (Sokač et al., 1976). Traces of such mineral assemblages can be recognized within the composition of LMF from LCC where quartz grains prevail (84-92\%), together with the occurrence of muscovite and feldspar (Table 2), while the presence of chlorite and kaolinite is confirmed by XRD analysis (Table 2). Potential source area could be found within the clastic-pyroclastic series of middle to upper Triassic (Figure 1C, unit 3), composed of shales, quartz-calcarenites, subgraywacke sandstones, calcilutites, breccias, and tuffitic rocks (Sokač et al., 1976). The subgraywacke shows pronounced domination of quartz, followed by chert, plagioclase, and platy minerals such as biotite, muscovite, and chlorite, all comparable with the composition of the analyzed samples (Table 2; Figure 5). Furthermore, other rocks within the clastic-pyroclastic series contain angular quartz, chert/radiolarite, and in smaller amounts fragments of older sandstones and shales, similar to the investigated samples. The predominance of pyroxenes among the THM in investigated samples points to the upper part of the middle Triassic clastic-pyroclastic series as the possible source rocks (Sokač et al., 1976). Pyroxenes, as chemically unstable detrital constituents, possibly indicate higher erosion rates of the source rocks, rapid transport, and short grain residence time in the river (Sevastjanova et al., 2012; Wacha et al., 2019). Although present, garnet grains are not the dominant phase within the composition of THM in LCC detrital sediments (Chapter 4.3, Figure 5) but the overall mineral assemblage is almost identical except for the absence of corundum and apatite. The apatite absence could be related to the sample preparation process and chemical dissolution. The relatively abundant wellrounded opaque grains within HMF resembles to Fe-Mn nodules, which are common in clastic cave sediments and Terra Rossa type soils and paleosols (Durn et al., 2018; unpublished data) (Figures 5D,E,H). Their occurrence could be related to the earlier mentioned Terra Rossa type soil in the Gračac karst polje (Figure 1B, Ivanović et al., 1973). To conclude, the mineral composition of the clastic detritus in which there is high proportion of quartz, followed by feldspars, muscovite, opaque minerals, biotite, chlorite, chromite, pyroxenes, zircon, rutile, garnets, epidote, zoisite/clinozoisite group minerals and chromite can indicate a diverse source area, but the one that is geographically connected to the nearby river Otuča catchment area.

\section{Sedimentary Facies and Depositional Environments}

Due to the unique characteristic of cave environments, it is sometimes difficult to interpret specific depositional conditions 


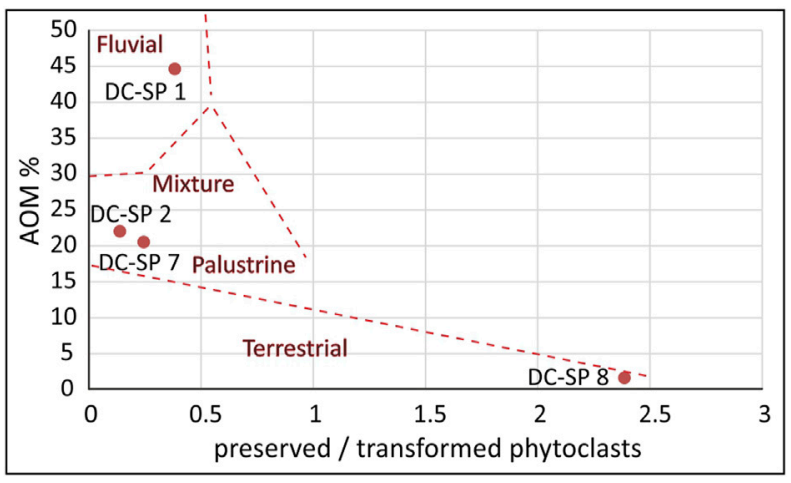

FIGURE 10 | Diagram for discrimination of depositional environments according to palynofacies analysis applied to samples from DC-SP profile in the Lower Cerovačka Cave with optical indices "AOM contents" (aquatic or microbial production) and "preserved/transformed ratio" (preservation degree of terrestrial plant debris) (according to Sebag et al., 2006).

within sequences of detrital cave deposits. Cave sediments represent the most complex terrestrial depositional environment where the law of superposition is often violated, facies are usually diachronous and re-deposition along the same cave passage is very common (White, 2007; Zupan Hajna et al., 2020 and references within). However, we were able to describe and interpret three lithofacies types within the sedimentary profile DC-SP in the LCC; the Breakdown facies (Bd), the Diamicton facies (Di) and the Slackwater facies (Sw) (Figure 3A; Table 1).

Sediments of the Bd facies are commonly formed by the gravitational collapse of the host-rock or speleothems from the ceiling of the caves. Such facies type has been described in other caves, and is considered as an autochthonous type of sediment (e.g., Bosch and White, 2004; White, 2007). The transport of material, in this case, is very short, as is confirmed by the angularity of collapsed blocks and poor sorting of the debris (Table 1; Figure 11A). Collapsed sediments are common near the cave entrances (e.g., Bočić et al., 2012; Haddad-Martim et al., 2017), although they can often be seen as big accumulations of unsorted boulders and cobbles on the floor of big chambers within caves (Fornós et al., 2014). Deposition is, besides other processes, often triggered by the cryofracturing process within cave channels during the cold periods (White, 2019). Hence, it can be assumed that sedimentation of the Bd facies in the channel of the LCC could also happen during a relatively cold period. That assumption is confirmed by palynological data which shows that the base of the investigated profile was formed during a period of cold and dry climate (see Chapter 4.4). The silty matrix within the $\mathrm{Bd}$ facies is the result of secondary infiltration (e.g., Martini, 2011) due to the existence of occasional and relatively insignificant water flow within the open cave channel. This is evidenced by the preserved/transformed phytoclast ratio according to Sebag et al. (2006). Even though this index was introduced by Sebag et al. (2006) for Holocene alluvial sediments, our data show a distribution of the index (Figure 10) which allows us to distinguish the paleoenvironment, confirming a transition from a fluvial paleoenvironment in the lower (older) part of the section (DC-SP $1-\mathrm{Bd}$ facies) to a non-aquatic terrestrial paleoenvironment toward the youngest part of the section (DCSP 8-Late Bronze Age). Such interpretation shows a good correlation with the sedimentological data. The appearance of microscopic-sized charcoal remains (Figure 7B) and possible traces of guano and bone remains (Table 2) between collapsed blocks of the $\mathrm{Bd}$ facies indicate that during the deposition of the Bd facies the cave channel was already fully developed and well connected to the surface in an open-air environment. Charcoal remains could indicate occurrences of wildfires in the area. Deposits of this type are formed during the vadose, air-filled stages of cave development (Hill, 1999). However, the distribution of palynofacies shown on Figure $\mathbf{1 0}$ in the lower part of the section, could also be a reflection of palynomorph transport by hydrological mechanism of cave drip water into the vadose cave channel.

Coevally to the Bd facies, the sediments of the Di facies were deposited (Figures 11A,D), as implied by their lateral contact. The red clayey silt resembles the Terra Rossa type soils and palaeosols whose genesis within the karst has not yet been unambiguously resolved. Polygenetic, detrital, and residual origins are most commonly mentioned (Durn et al., 2007). Similar red clayey-silty sediments in caves are interpreted as a composite of detritus introduced into the cave, and the insoluble residue from the dissolution of the host rock (e.g., Iacoviello and Martini, 2012). Mostly allogenic origin of the Di sediment within LCC is confirmed by mineralogy reflecting the composition of the river Otuča drainage area (Samples DC-SP 2, 3 in Table 2; Chapters 4.3 and 5.1). Although the vast majority of this interval is formed by finer sediment (Samples DC-SP 2, 3; Figure 4A), a significant number of larger clasts and bone fragments were found within (Figures 3A, 11A), could indicate depositional mechanisms by non-selective agents within cave specific environments. The aeolian contribution could also played important role in creating fine-grained sediment sequences within the cave. However, in the close vicinity of the LCC, there are no occurrences of loess on the surface (Figure 1C). Loess and loess-like deposits were widespread in the Adriatic region during oxygen isotope stage 3 (Wacha et al., 2018; Zhang et al., 2018). Nevertheless, aeolian sediments also play a significant role in the forming of polygenetic Terra Rossa type of soils (Durn et al., 2007) which were found in the river Otuča catchment area (Figure 1C, unit 9). According to paleontological data, it is necessary to mention that most probably intertwining of the depositional and biological processes resulted in today's distribution of clasts and fossil remains within the sediment. Despite the fact that all parts of the $U$. spelaeus body are represented (Chapter 4.5), there is a lack of articulated sets and high fragmentation with indications of certain movements and destruction of the faunal material within the sampled DC-SP 2 interval of Di facies (Table 1; Figure 3). In density-mediated attrition, low-density elements are quickly destructed and removed from the assemblage (Lyman, 1994), which does not explain why there are very few fragments of major limb bones. The post-depositional disturbance is possible. However, based on data on body parts representation and 
fragmentation, it is possible that a larger dispersal of the skeletal material occurred even before, when bear carcasses were lying on the fossil surface of the cave. Except for a single questionable finding of cut marks (Trbojević Vukičević and Babić, 2008), no traces of butchering were previously found on cave bear bones from LCC, so it is safe to assume that hominins were not responsible for the accumulation and dispersal of cave bear bones. Since the cave has probably been used for a very long time by several generations of cave bears (Malez, 1965b), lack of articulated skeletons can be also explained as a result of trampling by other cave bears. However, high fragmentation and underrepresentation of major long bones may be due to scavenging activities of large carnivore predators, whose presence should not be ruled out despite the lack of corresponding taphonomic traces within the analyzed assemblage. Bears used caves as shelter and for hibernation, and were often targeted by other large carnivores, mostly hyenas, who entered deep into caves in search of them (Diedrich, 2012). To conclude, described lack of complete skeletons or articulated sets, as well as high fragmentation undoubtedly indicate certain movements and destruction of the faunal material within the sediment, although taphonomic processes could have a significant influence (Chapter 4.5). Given the chaotic arrangement of clasts and random orientation of long bones with no visible textures in the clayey silt, the facies of the red clayey silt is interpreted as Di facies (e.g., Bosch and White, 2004; White, 2007; Haddad-Martim et al., 2017). This type of sediment could be formed by high-density debris flows within the caves and by the redeposition of older clastic cave deposits. Distinguishing facies types within this type of deposits is not always unambiguous because cave sediments deposited near cave entrances are often transported by nonselective mechanisms such as slumping, creeping, and collapsing. Such processes result in the fact that they are mainly built of similar ratios of silt, clay and sand, which makes it difficult to recognize unconformities (Haddad-Martim et al., 2017). The chaotic character of the Di facies (see description in Table 1) and the possible redeposition of the sediments, is supported by the results of the palynological analysis which shows signs of redeposition, for example high (relative) values of phytoclasts fragments especially corroded charcoal remains (Figure 10). Deposition of the Di facies sediments took place during a period of a colder and drier climate (Chapter 4.4). Such occurrence of poorly sorted fossiliferous sediments coincides with the results of previous research within the LCC (e.g., Malez, 1960b). Namely, the horizon of the Di facies could be related to deposits earlier described in the caves of the nearby Gračac area as sediment composed of reddish-brown phosphate clays with numerous osteological remains of the Late Pleistocene with traces of the Upper Paleolithic culture (Malez, 1960b; Ivanović et al., 1976). Those sediments were correlated to the Last Glacial Period. Although cave bears are one of the most abundant taxon recovered from Pleistocene cave sites in Croatia (Miracle, 1991), with Cerovačke caves being one of the most important cave bear sites (Paunović et al., 1999), our paleontological data are limited by the relatively modest sample size. Therefore, $U$. spelaeus remains within the investigated sequence cannot be used as a precise stratigraphic marker. The earliest appearance of the U. spelaeus dates back to the end of the Middle-Late Pleistocene transition, and it became extinct in central Europe during the LGM, around 24 ka BP (Kurtén, 1958, 1968; Pacher and Stuart, 2009). Within Dinaric karst there are dated cave bear specific sites (e.g., Križna jama) with ages of cave bear thanatocenoses around 47-45 ka and >94 ka BP (Bosák et al., 2012). To establish a chronological framework of the Di facies of the LCC luminescence dating was performed. Although it is a new approach in the region, the application of luminescence dating techniques has proven to be a suitable chronometer in cave settings (e.g., Montanari et al., 2019). In general, luminescence techniques enable the determination of depositional ages of sediments by determining the point in time when quartz or potassium-rich feldspar grains were last exposed to daylight during transport before final deposition (for the basic principles of luminescence dating see Preusser et al., 2008, Rhodes 2011; Wintle 2008). According to the obtained luminescence age, the sediment directly overlying cave bear remains entered the cave environment $53.7 \pm 6.9 \mathrm{ka}$ ago (Table 3), which correlates well with oxygen isotope stage 3 (OIS3). The obtained date does not necessarily indicate the time of deposition at the investigated site but the time when the sediment entered the cave environment. It also indicates that this part of the sequence is not older than $\sim 54 \mathrm{ka}$. The end of deposition of the Di facies is marked by a change in color from reddish to gray to yellow and the appearance of a discontinuous flowstone level (Table 1; Figure 11C). Similar it is also described in other caves of the investigated area (reddish-brown phosphate clays phase covered with flowstone-Ivanović et al., 1976).

A thin layer of laminated flowstone composed of columnar sparry calcite was determined with visible crystal growth directions (Supplementary Material S2). Millimeter-sized sparry calcite possibly indicate a relatively high growth rate of the flowstone. We assumed in situ genesis of the flowstone because platy fragments (Figures $\mathbf{9 A - C}$ ) are distributed at the same horizontal level with visible distinct uneven base/nucleation plane shoving traces of the underlying silty-clayey sediment (Supplementary Material S2). However, due to the thin and discontinuous horizon (Figure 3A), an allochthonous origin is not excluded. If in situ, the flowstone within the sedimentary profile is an indicator of change in the cave environment since their formation implies the absence of the detrital input (HaddadMartim et al., 2017). Flowstones could be formed from sheets of flowing water derived from fissures or major conduits (Fairchild et al., 2006) or as subaqueous flowstones fed with turbulent underground stream water (Wróblewski et al., 2017). As valuable marker horizons for dating, they were previously used in this region as source material for acquiring ${ }^{14} \mathrm{C}$ ages within caves (e.g., Bočić et al., 2012). Within this study the obtained ${ }^{14} \mathrm{C}$ age from the flowstone is supported by the $\mathrm{PIRIR}_{225}$ dating of the sediment horizon below the flowstone.

Comparing $\delta^{13} \mathrm{C}$ of the LCC speleothem sample (Table 4) of $5.3 \%$ to the Modric cave speleothem (Rudzka et al., 2012) that has a mean value of $-7.37 \%$ o $(2 \sigma=1.74 \%$ o), it could be concluded that the speleothem in the Modric cave had a lower amount of DCF. Therefore, the most likely date for the LCC speleothem would be the OxCal Reservoir function date 17,949-17,562 cal BC 


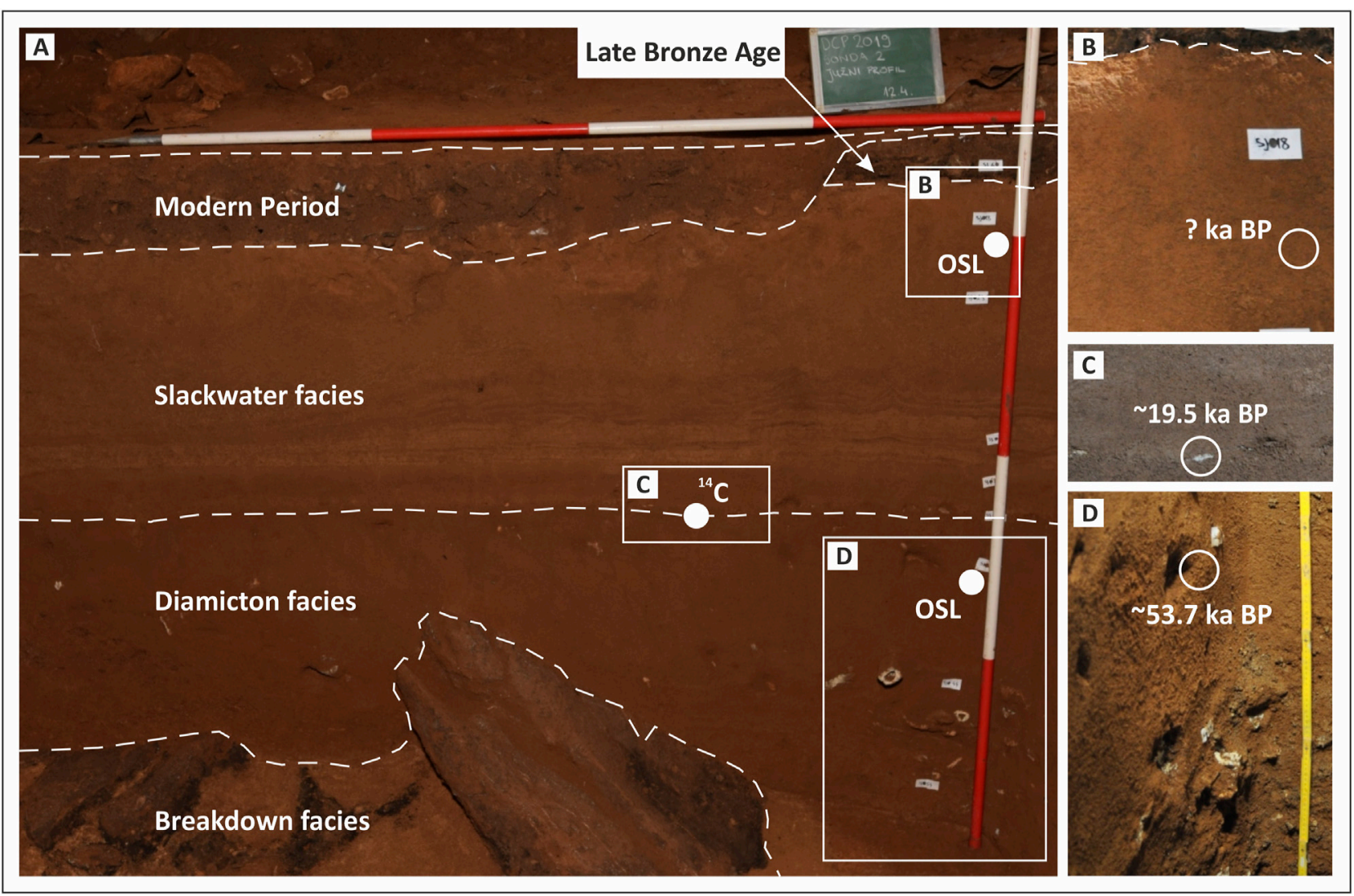

FIGURE 11 | Facies types and age on profile DC-SP in the Lower Cerovačka Cave (A) Facies distribution with indicated sampling spots, (B) detail from upper part of Slackwater facies with indicated sampling spot and luminescence age, (C) ${ }^{14} \mathrm{C}$ age with indicated sampling spot within flowstone fragment, (D) detail from diamicton facies with visible larger clasts and bone fragments of Ursus spelaeus with indicated sampling spot and luminescence age [authors of photographs (A) DTP, (B)-(D) NB]

(median 17,758 cal BC) for DCF $=15 \%$. The formation of a relatively thin flowstone layer within the sedimentary profile in LCC, therefore, could be related to the known period-related phenomena in the border zone between the temperate Mediterranean and the periglacial/glacial parts of Europe (Surić and Juračić, 2010) when the formation of speleothems were rare or slow. Speleothem deposition ceased during the Last Glacial Maximum (LGM) in most of Europe and began again around $15 \mathrm{ka}$ ago (Gascoyne, 1992; Lowe and Walker, 1997; Mihevc, 2001; Surić and Juračić, 2010). According to our data, the pronounced collapse processes and deposition of both Bd and Di facies sediments happened probably during local LGM, sometimes before $\sim 19.5$ ka from today $\left({ }^{14} \mathrm{C}\right.$ age 17,949-17,562 cal BC-Table 4, Figure 11C), before postglacial warming commenced. The Dinaric mountains were glaciated during the Middle and Late Pleistocene (Hughes and Woodward, 2009). Therefore, periglacial influence on the LCC could be expected. If the flowstone is allochthonous (e.g., spallation from the ceiling), the obtained age could still be used as the oldest possible date when deposition of the upper section of the DC-SP profile commenced. Sedimentation in a calm aquatic environment therefore set on after $\sim 19.5 \mathrm{ka}$ ago, as evidenced by the sedimentary filling of the cave channel which covers the flowstone marker horizon. This phase is characterized by gray to yellow laminated silt (Table 1; Figure 3A) which can be interpreted as slackwater deposit (Sw facies) (e.g., Bosch and White, 2004; White, 2007; Iacoviello and Martini, 2012; Ballesteros et al., 2017). These fine-grained sediments (Figure 4) entered the cave after flood events and settled during calmer conditions with very low flow velocities (often submerged cave channels). The allogenic origin of the $\mathrm{Sw}$ sediment is confirmed by the mineralogy, reflecting the composition of the river Otuča drainage area (Samples DC-SP 5-7 in Table 2; Chapters 4.3 and 5.1). Although the detritus was transported underground by turbulent flows rich in suspended sediment, the final depositional mechanism of this sediment type is very likely related to deposition from stagnant water suspension, as evidenced by the particle size characteristics and the lamination of the sediment. This is also confirmed by the fining upwards sequence observed in the upper part of the Sw facies interval (Figure 4B; Table 1). Slight reduction of the grain size from the base to the top indicating a decrease in the hydrodynamic energy conditions of the cave, is commonly observed within the Sw facies (Fornós et al., 2014). This is also confirmed by the palynofacies analysis, results of which indicate sedimentation in a calm palustrine environment 
(Figure 10). However, the laminated structure of the sediment in the lower part of the SW facies followed by a slight increase of the sand content (Figures 3A, 4B), described as vertical alterations of silty laminae and silty-sandy laminae (Table 1), could also resemble sediments deposited in stagnant hydrological conditions in regions prone to glaciation. Nearby areas of southern Velebit Mt. were prone to glaciation, documented with morphological moraine features and with glacial and glacio-fluvial sediments (Nikler, 1973; Krklec et al., 2015; Marjanac and Marjanac, 2016; Velić et al., 2017). The retreat of mountain glaciers in the southern Velebit Mt. is therefore dated roughly around 20.7-22.7 ka ago (Sarikaya et al., 2020). Even so, there is no data about glacial chronology and processes in the very close vicinity of LCC. It should be mentioned that warming and deglaciation in the inland part of the Dinarides commenced mainly after $12.5 \mathrm{ka} \mathrm{BP}$. It can be seen from increased speleothem growth in the Dinaric karst (Horvatinčić et al., 2003). Hence, we assume that it is highly possible to recognize glacial/periglacial influence on the deposition of $\mathrm{Sw}$ facies. According to our data, the $\mathrm{Sw}$ sediments were deposited during the Late Pleistocene (starting after $\sim 19.5 \mathrm{ka}$ ). In caves within glaciated regions, similar varve-like deposits are common (Ford and Williams, 2007). Even though the grain-size curves of the $\mathrm{Sw}$ facies (Figure 4A) resemble the varve-like sediments (Valen et al., 1997; Ford and Williams, 2007), the glacial-related depositional environment through the whole profile of the $\mathrm{Sw}$ facies sediments is ambiguous and needs further proof. Grain-size distribution curves themselves do not point to an unambiguous conclusion, it is necessary to compare them with known sediment ages to resolve the glacial-related origin of the laminae (Tischler et al., 2020).

The termination of allogenic siliciclastic sedimentation in an aquatic environment and consequently the end of the ponor function of this part of the LCC channel cannot be precisely dated within our research. Nevertheless, our data revealed a relatively young age in comparison to the known data within the wider area of the Dinaric karst where cave sediments cover the time span of the last 5 Ma years (Zupan Hajna et al., 2020; Zupan Hajna et al., 2021). We can conclude that this pronounced sedimentary environment shift is visible in the profile DC-SP with the onset of a Holocene Late Bronze Age layer (Tresić Pavičić, 2020). As known, the cessation of allogeneic sedimentation in caves is mostly controlled by tectonics and therefore related to changes in the hydrological regimes due to the separation of cave systems from active watercourses (Zupan Hajna et al., 2020). At Postojnska Cave, the sequence follows the series of events: formation of the fault, growth of the initial conduit due to groundwater circulation through the fault, infilling of the conduit with allogenic sediment, abandonment due to regional base level lowering, and continued motion along the fault (Sasowsky et al., 2003). Locally in LCC, it could be related to the permanent neotectonic uplift of this area (Prelogović, 1975). Especially pronounced uplift along the main NW-SE faults, e.g., along the Lika fault (Figure 1C), was recorded during the Pliocene and Quaternary (Prelogović, 1975). Maximum uplift of the local mountains was calculated of up to $1,200 \mathrm{~m}$, with vertical shifts on individual faults averaging from 300 to $500 \mathrm{~m}$ (Prelogović, 1975). The sedimentary profile DC-SP, and the obtained data therefore possibly reveal the sedimentation history of the youngest inactive cave level within Mt. Crnopac. The same phases in the development of allogenic cave sediments occurred earlier in the higher cave levels within the mountain. It is evidenced with similar facies types (Sw) of detrital sediments which were found within the hypsometrically highest horizontal level of the todays CCS (Talaja and Kurečić, 2017). Considering that caves and their sediments are often related to the former base level and can conserve this information for long periods (Neuhuber et al., 2021), the average offset rate of local ongoing uplift/base level drop can be roughly estimated. Considering the relative displacement value of $\sim 80 \mathrm{~m}$ between today's LCC entrance (at $624 \mathrm{~m}$ a.s.l.), and the recent active ponor phase on the polje level we have calculated the relative displacement rate. It is based on the obtained ${ }^{14} \mathrm{C}$ age of 17,949-17,562 cal BC (before approximately $19.5 \mathrm{ka}$ from today) of the flowstone strata identified within the DC-SP profile (Table 4). The displacement rate gives us a relatively high value up to $\sim 0.004 \mathrm{~m}$ per year. The calculated result is higher and not unambiguously comparable with fault slip rates calculated in the area of External Dinarides (Kastelic and Carafa, 2012). Therefore, due to scarce data without numerous variables, we believe that the computed rate could only be used as a rough estimation and basis for further research. Even if we use the combination of absolute and relative methods in order to get an accurate and robust age estimate (Häuselman et al., 2015), the critical problems identified are lack of data regarding the timing of the cessation of the allogenic sediment input. The archeological data suggests that the LCC was used for specific purposes during the Late Bronze Age (Tresić Pavičić, 2020), such as food storage and as a temporary dwelling in specific circumstances which surely indicate already ceased sediment input. However, due to the possible large time gap between the cessation of the $\mathrm{Sw}$ deposition and the onset of the Late Bronze Age, we cannot use that data for accurate calculations.

\section{CONCLUSION}

The allogenic cave deposits in Croatia have been poorly explored, especially from the point of view of their origin and depositional mechanisms. Numerical dating is also absent. This is the first detailed study of detrital cave sediments with reliable luminescence age constraints in the Croatian part of the Dinaric karst region. The presented data are a significant contribution to solving the complex stratigraphy and genesis of a multilevel cave system of Mt. Crnopac and Dinaric karst. Our conclusions are as follows:

- The genesis of the LCC and its entrance channel is related to the denudation effect of the sinking waters of the Gračac karst polje, mainly under saturated conditions.

- Within the investigated sedimentary profile (DC-SP) three lithofacies types were identified: Breakdown deposits (Bd), Diamicton deposits (Di), and Slackwater deposits (Sw) 
covered with an archaeological Late Bronze Age and Modern period deposits.

- The mineral composition of cave detrital sediments points to an allochthonous origin, derived from the wider Otuča river catchment area.

- The source rocks which derived the siliciclastic detritus found within the entrance channel of the LCC belong to the upper Carboniferous clastic series, middle to upper Triassic clastic-pyroclastic series, Terra Rossa type of sediments, and arguably in some extent to the insoluble remnant of the host rock.

- Sedimentary facies analysis coupled with the palynofacies analysis revealed changes in depositional events within the LCC, ranging from intensive collapse processes with fluvial influence through re-deposition by mechanisms of high density flows to the forming of stagnant water environments with laminated sediments, and finally to the terrestrial environment with pronounced human activity.

- Numerous bones of U. spelaeus were found, giving us a broad estimation of the stratigraphic position of the $\mathrm{Di}$ facies sediments spanning from the early Late Pleistocene to the Last Glacial Maximum.

- The lack of complete skeletons or even articulated sets, as well as high fragmentation, indicate movements and destruction of the faunal material as a result of taphonomic processes coupled with re-deposition within the fossiliferous interval.

- Deposition of first allochthonous detrital cave sediment sequence (Di facies) within the LCC channel commenced around or after $\sim 54 \mathrm{ka}$ ago as evidenced by luminescence dating. For the first time in Croatia, luminescence dating contributed to resolving the chronostratigraphy of clastic sedimentary sequence within the cave environment.

- The major shift in sedimentation mechanisms between collapse and redeposition processes, and deposition within stagnant water conditions commenced through the period after $19.5 \mathrm{ka}$ from today up to the onset of the Late Bronze Age.

- The cessation of allogenic sedimentation within the LCC is related to the permanent neotectonic uplift of the area, especially pronounced uplift along the main NW-SE faults.

\section{DATA AVAILABILITY STATEMENT}

The original contributions presented in the study are included in the article/Supplementary Material, further inquiries can be directed to the corresponding author.

\section{REFERENCES}

Adamiec, G., and Aitken, M. (1998). Dose-rate Conversion Factors: Update. Ancient TL. 16, 37-50.

Auclair, M., Lamothe, M., and Huot, S. (2003). Measurement of Anomalous Fading for Feldspar IRSL Using SAR. Radiat. Measurements. 37, 487-492. doi:10.1016/ s1350-4487(03)00018-0

\section{AUTHOR CONTRIBUTIONS}

TK conceptualized, drafted and prepared the paper with the contribution of all coauthors. DP (archaeology), TK, NB, and LW (geology and sedimentology) conducted the field work and sampling. TK conducted detailed sedimentological and mineralogical analysis as well as laser diffraction particle size distribution. NB performed morphological analysis. KB performed palynological, SR macropaleontological and AG XRD analysis. CL performed luminescence dating and all related analyses and data evaluation. AS performed radiocarbon dating. DP acquired photogrammetric data. LR performed laser scanning of the cave and prepared the 3D model. MF accompanied the luminescence dating part and gave advice during lab work and elaboration of the manuscript. All authors reviewed the manuscript and approved the final version.

\section{ACKNOWLEDGMENTS}

The authors are thankful to the archaeological firm Kaducej Ltd. which conducted rescue archaeological excavation at LCC, from March to May 2019. Excavation gives us insight into geological layers, and the opportunity to sample sediments. All relevant photogrammetric data about the test trench was also provided by Kaducej Ltd. The archaeological excavation was the first part of the revitalization project: Centre of Excellence Cerovac Caves Sustainable Management of Natural Heritage and the Karst Underground, under the direction of Public Institution Park prirode Velebit with partners Zadar County, Public Institution Natura-Jadera and Zagreb Speleological Union, co-funded by the European Regional Development Fund. The authors would also like to thank to Mirjana Drušković, Dragica Kovačić, Antun Škrtić and Damir Galović from Croatian Geological Survey for the sample preparations. This work was partially funded by the University of Zagreb within the project "Geomorphological and hydromorphological research at selected sites of the Dinaric Karst in Croatia." The research was also supported by the Croatian Geological Survey through program funding provided by the Croatian Ministry of Science and Education. The authors would like to thank the editor (Dr. Aurel Perșoiu), and the two reviewers (Dr. Andrea Zerboni, and Dr. Christos Pennos) for their comments.

\section{SUPPLEMENTARY MATERIAL}

The Supplementary Material for this article can be found online at: https://www.frontiersin.org/articles/10.3389/feart.2021.672229/ full\#supplementary-material

Bahun, S. (1963). Geološki Odnosi Okolice Donjeg Pazarišta U Lici (Trijas I Tercijarne Jelar-Naslage) [Geological Relations of the Surroundings of Donje Pazarište in Lika - in Croatian]. - Geološki vjesnik. 16, 161-170.

Bahun, S. (1974). Tektonogeneza Velebita I Postanak Jelar Naslaga [Tectonogenesis of Mt. Velebit and the Origin of the Jelar Deposits - in Croatian]. Geološki vjesnik 27, 35-51.

Bajo, P., Borsato, A., Drysdale, R., Hua, Q., Frisia, S., Zanchetta, G., et al. (2017). Stalagmite Carbon Isotopes and Dead Carbon Proportion (DCP) in a Near- 
Closed-System Situation: An Interplay between Sulphuric and Carbonic Acid Dissolution. Geochimica et Cosmochimica Acta. 210, 208-227. doi:10.1016/ j.gca.2017.04.038

Bakarić, L. (2017). "Japodi [Iapodes]," in In Iapodes - the Forgotten Highlanders [in Croatian]. Editor L. Bakarić (Zagreb: Archaeological museum Zagreb), 21-60.

Barišić, T. (2017). Perspektive Spajanja Velikih Jama Crnopca [Perspectives of Connecting the Large Pits of the Mt. Crnopac - in Croatian]. Speleolog. 65 (1), 26-31. Available at: https://hrcak.srce.hr/204709.

Bickel, L., Lüthgens, C., Lomax, J., and Fiebig, M. (2015a). Luminescence Dating of Glaciofluvial Deposits Linked to the Penultimate Glaciation in the Eastern Alps. Quat. Int. 357, 110-124. doi:10.1016/j.quaint.2014.10.013

Bickel, L., Lüthgens, C., Lomax, J., and Fiebig, M. (2015b). The Timing of the Penultimate Glaciation in the Northern Alpine Foreland: New Insights from Luminescence Dating. Proc. Geologists' Assoc. 126, 536-550. doi:10.1016/ j.pgeola.2015.08.002

Blečić-Kavur, M. (2014). Na Razmeđu Svjetova Za Prijelaza Milenija: Kasno Brončano Doba Na Kvarneru [At the Crossroads of Worlds at the Turn of the Millennia: The Late Bronze Age in the Kvarner-in Croatian]. Musei Archaeologici Zagrabiensis Catalogi et Monographiae. XI, 121. doi:10.1163/ 9789004416604_007

Bočić, N., Božić, V., Buzjak, N., Dražina, T., Knajs, R., Miculinić, K., et al. (2016). Stručna Podloga Za Izradu Projektno-Tehničke Dokumentacije Za Unutarnje I Vanjsko Uređenje Turističke Infrastrukture S Geodetskom Snimkom U Interesnom Žarištu Projekta U Zoni C: "Gornja I Donja Cerovačka Špilja" [Expert Basis for the Preparation of Project-Technical Documentation for Internal and External Arrangement of Tourist Infrastructure with a Geodetic Survey in the Focus of the Project in Zone C: "Upper and Lower Cerovačke Caves" - in Croatian], Expert Study. Zagreb: Speleological club Željezničar, 248

Bočić, N., Faivre, S., Kovačić, M., and Horvatinčić, N. (2012). Cave Development under the Influence of Pleistocene Glaciation in the Dinarides-an Example from Štirovača Ice Cave (Velebit Mt., Croatia). Z. für Geomorphologie. 56 (4), 409-433. doi:10.1127/0372-8854/2012/0083

Bočić, N., Pahernik, M., and Faivre, S. (2019). Geomorfološka Obilježja Sjevernog Velebita [The Geomorphological Features of Northern Velebit]. Senjski zbornik. 46, 5-36. [in Croatian, with English Summary]. doi:10.31953/sz.46.1.1

Bosák, P. (2002). "Karst Processes from the Beginning to the End: How Can They Be Dated?," in In: Evolution of Karst: From Prekarst to Cessation. Editor F. Gabrovšek (Postojna-Ljubljana): Carsologica, Založba ZRC), 191-223.

Bosák, P., Pruner, P., Zupan Hajna, N., Hercman, H., Mihevc, A., and Wagner, J. (2012). Križna Jama (SW Slovenia): Numerical-And Correlated-Ages from Cave bear-bearing Sediments. Ac. 39 (3), 133. doi:10.3986/ac.v39i3.82

Bosch, R. F., and White, W. B. (2004). "Lithofacies and Transport of Clastic Sediments in Karstic Aquifers," in "Lithofacies and Transport of Clastic Sediments in Karstic Aquifers" in: Studies of Cave Sediments: Physical and Chemical Records of Paleoclimate. Editors I. D. Sasowsky and J. Mylroie (Boston: Springer), 1-22. doi:10.1007/978-1-4419-9118-8_1

Bøtter-Jensen, L., Andersen, C., Duller, G., and Murray, A. (2003). Developments in Radiation, Stimulation and Observation Facilities in Luminescence Measurements. Radiat. Measurements 37, 535-541. doi:10.1016/s13504487(03)00020-9

Bøtter-Jensen, L., Bulur, E., Duller, G., and Murray, A. (2000). Advances in Luminescence Instrument Systems. Radiat. Measurements. 32, 523-528. doi:10.1016/s1350-4487(00)00039-1

Bronk Ramsey, C. (2009). Bayesian Analysis of Radiocarbon Dates. Radiocarbon. 51 (1), 337-360. doi:10.1017/s0033822200033865

Bronk Ramsey, C. (2016). The OxCal Program V 4.2. Oxford: The Oxford Radiocarbon Accelerator Unit, University of Oxford. Available at: https:// c14.arch.ox.ac.uk/oxcal/OxCal.html

Caver Bob (2021). World Longest Caves Compiled by Bob Gulden. Available at: http://www.caverbob.com/wlong.htm (Accessed February 02, 2021).

Chang, S. J., Blake, R. E., Stout, L. M., and Kim, S. J. (2010). Oxygen Isotope, Microtextural and Molecular Evidence for the Role of Microorganisms in Formation of Hydroxylapatite in limestone Caves, South Korea. Chem. Geology. 276, 209-224. doi:10.1016/j.chemgeo.2010.06.007

Croatian Geological Survey (2009). Geološka Karta Republike Hrvatske, M 1: 300.000 [Geological Map of the Republic of Croatia, M 1: 300.000-in Croatian].- Hrvatski Geološki Institut. Zagreb: Zavod za geologiju.
Croatian Mountaineering Association (2021). List of the Longest Caves in Croatia. Available at: https://www.hps.hr/specijalisticke-djelatnosti/speleologija/ najvece-hrvatske-spilje/ (Accessed February 02, 2021).

Cunningham, A. C., and Wallinga, J. (2012). Realizing the Potential of Fluvial Archives Using Robust OSL Chronologies. Quat. Geochronol. 12, 98-106. doi:10.1016/j.quageo.2012.05.007

Czuppon, G., Bočić, N., Buzjak, N., Óvári, M., and Molnár, M. (2018). Monitoring in the Barać and Lower Cerovačka Caves (Croatia) as a Basis for the Characterization of the Climatological and Hydrological Processes that Control Speleothem Formation. Quat. Int. 494, 52-65. doi:10.1016/ j.quaint.2018.02.003

Diedrich, C. G. (2012). Cave bear Killers and Scavengers from the Last Ice Age of central Europe: Feeding Specializations in Response to the Absence of mammoth Steppe Fauna from Mountainous Regions. Quat. Int. 255, 59-78. doi:10.1016/j.quaint.2011.06.048

Durn, G. (2003). Terra Rossa in the Mediterranean Region: Parent Materials, Composition and Origin. Geol. Croat. 56 (1), 83-100. doi:10.4154/GC.2003.06

Durn, G., Aljinović, D., Crnjaković, M., and Lugović, B. (2007). "Chapter 28 Heavy and Light Mineral Fractions Indicate Polygenesis of Extensive Terra Rossa Soils in Istria, Croatia," in "Heavy and Light mineral Fractions Indicate Polygenesis of Extensive Terra Rossa in Istria, Croatia" in: Heavy Minerals in Use. Editors M. A. Mange and D. T. Wrigt (Amsterdam: Elsevier), 701-737. doi:10.1016/ s0070-4571(07)58028-3

Durn, G., Ćorić, R., Tadej, N., Barudžija, U., Rubinić, V., and Husnjak, S. (2014). Bulk and clay mineral Composition Indicate Origin of Terra Rossa Soils in Western Herzegovina. Geol. Cro 67 (3), 171-183. doi:10.4154/GC.2014.13

Durn, G., Wacha, L., Bartolin, M., Rolf, C., Frechen, M., Tsukamoto, S., et al. (2018). Provenance and Formation of the Red Palaeosol and Lithified Terra Rossa-like Infillings on the Island of Susak: A High-Resolution and Chronological Approach. Quat. Int. 494, 105-129. doi:10.1016/ j.quaint.2017.11.040

Fairchild, I. J., Smith, C. L., Baker, A., Fuller, L., Spötl, C., Mattey, D., et al. (2006). Modification and Preservation of Environmental Signals in Speleothems. EarthScience Rev. 75 (1-4), 105-153. doi:10.1016/j.earscirev.2005.08.003

Filipčić, A. (1998). Klimatska Regionalizacija Hrvatske Po W. Köppenu Za Standardno Razdoblje 1961.-1990. U Odnosu Na Razdoblje 1931-1960 [Climatic Regionalization of Croatia According to W. Köppen for the Standard Period 1961-1990 in Relation to the Period 1931-1960-in Croatian, with English Summary]. Acta Geographica Croatica 34, 1-15.

Ford, D., and Williams, P. (2007). Karst Hydrogeology and Geomorphology. Chichester: John Wiley \& Sons. doi:10.1002/9781118684986

Fornós, J., Ginés, J., Gràcia, F., Merino, A., Gómez-Pujol, L., and Bover, P. (2014). Cave deposits and sedimentary processes in Cova des Pas de Vallgornera (Mallorca, Western Mediterranean). Ijs. 43, 159-174. doi:10.5038/1827806X.43.2.5

Galbraith, R. F., Roberts, R. G., Laslett, G. M., Yoshida, H., and Olley, J. M. (1999). Optical Dating of Single and Multiple Grains of Quartz from Jinmium Rock Shelter, Northern Australia: Part I, Experimental Design and Statistical Models. Archaeometry. 41, 339-364. doi:10.1111/j.14754754.1999.tb00987.x

García, J.-L., Maldonado, A., de Porras, M. E., Nuevo Delaunay, A., Reyes, O., Ebensperger, C. A., et al. (2019). Early Deglaciation and Paleolake History of Río Cisnes Glacier, Patagonian Ice Sheet $\left(44^{\circ} \mathrm{S}\right)$. Quat. Res. 91, 194-217. doi:10.1017/qua.2018.93

Gascoyne, M. (1992). Palaeoclimate Determination from Cave Calcite Deposits. Quat. Sci. Rev. 11, 609-632. doi:10.1016/0277-3791(92)90074-I

Georgiadis, I., Chatzopoulou, K., Kantiranis, N., Ioakeimidis, I., and Tsirambides, A. (2019). Petrography and Provenance of Floor Sediments from the Loutra Almopias Cave (Pella, Macedonia, Greece). Int. J. Speleology. 48, 237-248. doi:10.5038/1827-806X.48.3.2271

Ghenciu, M. (2017). Clay Minerals in Caves from Northwestern Oltenia, Muzeul Olteniei Craiova. Oltenia. Studii Și Comunicări. Stiințele Naturii. 33 (1), 39-47.

Grimm, E. C. (1991). TILIA and TILIA.GRAPH Computer Programs. Springfield: Illinois State Museum.

Haddad-Martim, P. M., Hubbe, A., Giannini, P. C. F., Auler, A. S., Piló, L. B., Hubbe, M., et al. (2017). Quaternary Depositional Facies in Cave Entrances and Their Relation to Landscape Evolution: The Example of Cuvieri Cave, Eastern Brazil. Catena. 157, 372-387. doi:10.1016/j.catena.2017.05.029 
Häuselmann, Ph. (2011). UIS Mapping Grades. Int. J. Speleology. 40, IV-VI. doi:10.18273/rev.medicasuis

Häuselmann, P., Mihevc, A., Pruner, P., Horáček, I., Čermák, S., Hercman, H., et al. (2015). Snežna Jama (Slovenia): Interdisciplinary Dating of Cave Sediments and Implication for Landscape Evolution. Geomorphology. 247, 10-24. doi:10.1016/ j.geomorph.2014.12.034

HIGH SCORE PLUS (2016). VERSION 4.5 (4.5.0.22741). Netherlands: PANalytical B.V. Almeo.

Hill, C. A. (1999). Sedimentology and Paleomagnetism of Sediments, Kartchner Caverns, Arizona. J. Cave Karst Stud. 61, 79-83.

Hill, C. A., and Forti, P. (1997). Cave minerals of the world (2nd ed.). (Huntsville, Alabama: National Speleological Society), 464.

Horvatinčić, N., Krajcar Bronić, I., and Obelić, B. (2003). Differences in the ${ }^{14} \mathrm{C}$ Age, $\delta^{13} \mathrm{C}$ and $\delta^{18} \mathrm{O}$ of Holocene Tufa and Speleothem in the Dinaric Karst. Palaeogeogr. Palaeoclimatol. Palaeoecol. 193, 139-157. doi:10.1016/S00310182(03)00224-4

Hua, Q., Cook, D., Fohlmeister, J., Penny, D., Bishop, P., and Buckman, S. (2017). Radiocarbon Dating of a Speleothem Record of Paleoclimate for Angkor, Cambodia. Radiocarbon. 59 (6), 1873-1890. doi:10.1017/ RDC.2018.1310.1017/rdc.2017.115

Hughes, P. D., and Woodward, J. C. (2009). "Glacial and Periglacial Environments," in The Physical Geography of the Mediterranean. Editor J. C. Woodward (Oxford University Press), 353-383.

Huntley, D., and Baril, M. (1997). The K Content of the K-Feldspars Being Measured in Optical and Thermoluminescence Dating. Ancient TL. 15, 11-13.

Huntley, D. J., and Lamothe, M. (2001). Ubiquity of Anomalous Fading in K-Feldspars and the Measurement and Correction for it in Optical Dating. Can. J. Earth Sci. 38, 1093-1106. doi:10.1139/e01-013

Iacoviello, F., and Martini, I. (2012). Provenance and Geological Significance of Red Mud and Other Clastic Sediments of the Mugnano Cave (Montagnola Senese, Italy). Ijs. 41, 317-328. doi:10.5038/1827-806x.41.2.17

Ivanović, A., Sakač, K., Marković, S., Sokač, B., Šušnjar, M., Nikler, L., et al. (1973). Osnovna Geološka Karta SFRJ 1:100000, List Obrovac L33-140 [Basic Geological Map in Scale of 1:100,000 - Sheet Obrovac L33-140 - in Croatian]. Institut Za Geološka Istraživanja, Zagreb (1962-1967). Beograd: Savezni geološki institut.

Ivanović, A., Sakač, K., Marković, S., Sokač, B., Šušnjar, M., Nikler, L., et al. (1976). Osnovna Geološka Karta SFRJ 1:100000, Tumač Za List Obrovac L33-140 [Guide for Basic Geological Map in Scale of 1:100,000 - Sheet Obrovac L33140 - in Croatian]. Institut Za Geološka Istraživanja (1962-1967). Zagreb: Savezni geološki zavod, Beograd.

Kastelic, V., and Carafa, M. M. C. (2012). Fault Slip Rates for the Active External Dinarides Thrust-and-fold belt. Tectonics. 31, 33-39. doi:10.1029/ 2011TC003022

Korbar, T. (2009). Orogenic Evolution of the External Dinarides in the NE Adriatic Region: a Model Constrained by Tectonostratigraphy of Upper Cretaceous to Paleogene Carbonates. Earth-Science Rev. 96 (4), 296-312. doi:10.1016/ j.earscirev.2009.07.004

Krajcar Bronić, I., Horvatinčić, N., Sironić, A., Obelić, B., Barešić, J., and Felja, I. (2010). A New Graphite Preparation Line for AMS 14C Dating in the Zagreb Radiocarbon Laboratory. Nucl. Instr. Methods Phys. Res. B. 268, 943-946. doi:10.1016/j.nimb.2009.10.070

Krajcar Bronić, I., Horvatinčić, N., Srdoč, D., and Obelič, B. (1986). On the Initial ${ }^{14} \mathrm{C}$ Activity in Karst Aquifers with Short Mean Residence Time. Radiocarbon. 28, 436-440. doi:10.1017/S0033822200007566

Krajcar Bronić, I., Horvatinčić, N., Srdoč, D., and Obelič, B. (1992). Experimental Determination of the 14C Initial Activity of Calcareous Deposits. Radiocarbon 34, 593-601.

Kreutzer, S., Schmidt, C., Fuchs, M., Dietze, M., and Fuchs, M. (2012). Introducing an R Package for Luminescence Dating Analysis. Ancient TL. 30, 1-8. doi:10.1007/springerreference_77324

Krklec, K., Domínguez-Villar, D., and Perica, D. (2015). Depositional Environments and Diagenesis of a Carbonate till from a Quaternary Paleoglacier Sequence in the Southern Velebit Mountain (Croatia). Palaeogeogr. Palaeoclimatol. Palaeoecol. 436, 188-198. doi:10.1016/ j.palaeo.2015.07.004

Krumm, S. (1994). Centrifuge, Erlangen. Available at: http://www.ccp14.ac.uk/ccp/ web-mirrors/krumm/html/software/winsoft.html.
Kuhta, M., and Stroj, A. (2005). "The Speleogenesis of the Caves in Crnopac Mt. Area," in Proceeding. $14^{\text {th }}$ International Congress of Speleology. Editor C. Petreas Athens, Greece, 46-48.

Kulig, G. (2005). Erstellung einer Auswertesoftware zur Altersbestimmung mittels Lumineszenzverfahren unter spezieller Berücksichtigung des Einflusses radioaktiver Ungleichgewichte in der 238U-Zerfallsreihe. 35 p., B.Sc. thesis. Freiberg: Technische Universität Bergakademie Freiberg.

Kurtén, B. (1958). Life and Death of the Pleistocene Cave Bear. Acta Zoologica Fennica. 95, 1-59.

Kurtén, B. (1968). Pleistocene Mammals of Europe. London: Weidenfeld and Nicolson. doi:10.4324/9781315126470

Leroy, S. A. G., Marret, F., Gibert, E., Chalié, F., Reyss, J.-L., and Arpe, K. (2007). River Inflow and Salinity Changes in the Caspian Sea during the Last 5500 Years. Quat. Sci. Rev. 26, 3359-3383. doi:10.1016/ j.quascirev.2007.09.012

Longin, R. (1971). New Method of Collagen Extraction for Radiocarbon Dating. Nature. 230, 241-242. doi:10.1038/230241a0

Lowe, J. J., and Walker, M. J. C. (1997). Reconstructing Quaternary Environments. 2nd ed. London: Routledge, 468. doi:10.4324/9781315844312

Lüthgens, C., Böse, M., and Preusser, F. (2011). Age of the Pomeranian IceMarginal Position in Northeastern Germany Determined by Optically Stimulated Luminescence (OSL) Dating of Glaciofluvial Sediments. Boreas 40, 598-615. doi:10.1111/j.1502-3885.2011.00211.x

Lüthgens, C., Neuhuber, S., Grupe, S., Payer, T., Peresson, M., and Fiebig, M. (2017). Geochronological Investigations Using a Combination of Luminescence and Cosmogenic Nuclide Burial Dating of Drill Cores from the Vienna Basin. $z$ dgg 168, 115-140. doi:10.1127/zdgg/2017/0081

Lyman, R. L. (1994). Vertebrate Taphonomy. Cambridge: Cambridge University Press. doi:10.1017/CBO9781139878302

Malez, M. (1958). Cerovačke Pećine-Najveće U Hrvatskoj [Cerovačke Caves - the Largest in Croatia - in Croatian]. Priroda. 45, 6.

Malez, M. (1956). Explorationes recentes des cavernes eu Croatie [Recent explorations of caves in Croatia - in French]. Acta geologica 1, 149.

Malez, M. (1965a). Nalazišta Fosilnih Hominida U Hrvatskoj [Fossil Hominid Sites in Croatia - in Croatian]. Geološki vjesnik 18, 2.

Malez, M. (1965b). Cerovačke Pećine [Cerovačke Caves - in Croatian]. Zagreb: Izdanja Speleološkog društva Hrvatske, 1.

Malez, M. (1960a). Paleontološka Istraživanja I Speleološka Rekognosciranja U 1959 Godini [Paleontological Research and Speleological Reconnaissance in 1959 - in Croatian]. Zagreb: Ljetopis JAZU, 66.

Malez, M. (1960b). Rad Na Speleološkom Istraživanju U Hrvatskoj [Work on Speleological Research in Croatia - in Croatian]. Ljetopis JAZU. 64, 289-307.

Mange, M. A., and Maurer, H. F. W. (1992). Heavy Minerals in Colour. (London: Chapman and Hall), 151.

Marjanac, T., and Marjanac, L. (2016). The Extent of Middle Pleistocene Ice Cap in the Coastal Dinaric Mountains of Croatia. Quat. Res. 85 (3), 445-455. doi:10.1016/j.yqres.2016.03.006

Marković, J., Bočić, N., and Pahernik, M. (2016). Prostorni Raspored I Gustoća Ponikva Jugoistočnog Velebita [Spatial Distribution and Density of Dolines in the southeastern Velebit Area - in Croatian and English]. Geoadria. 20/1, 1-28. doi:10.15291/geoadria.23

Marom, A., McCullagh, J. S. O., Higham, T. F. G., and Hedges, R. E. M. (2013). Hydroxyproline Dating: Experiments on the 14C Analysis of Contaminated and Low-Collagen Bones. Radiocarbon. 55 (2), 698-708. doi:10.1017/ S0033822200057854

Martini, I. (2011). Cave Clastic Sediments and Implications for Speleogenesis: New Insights from the Mugnano Cave (Montagnola Senese, Northern Apennines, Italy). Geomorphology. $134 \quad(3-4), \quad 452-460 . \quad$ doi:10.1016/ j.geomorph.2011.07.024

Mejdahl, V. (1979). Thermoluminescence Dating: Beta-Dose Attenuation in Quartz Grains. Archaeometry 21, 61-72. doi:10.1111/j.14754754.1979.tb00241.x

Mihevc, A. (2001). Speleogeneza Divaškega Krasa [The Speleogenesis Of the Divača Karst-in Slovenian]. Ljubljana: - Založba ZRC, 180.

Miko, S., Kuhta, M., and Kapelj, S. (2001). "Bat Guano Influence on the Geochemistry of Cave Sediments from Modrič Cave, Croatia," in Proceeding, 13th International Congress of Speleology, 4th Speleological Congress of Latin América and Caribbean, 26th Brazilian Congress of 
Speleology. Editor M. A. Rasteiro (Brazil: SBE - Sociedade Brasileira de Espeleologia), 188-192.

Miracle, P. (1991). Carnivore Dens or Carnivore Hunts? A Review of Upper Pleistocene Mammalian Assemblages in Croatia and Slovenia. Rad HAZU, knj. 458, 193-219.

Montanari, A., Fiebig, M., Lomax, J., Mainiero, M., Mariani, S., and Lüthgens, C. (2019). "Luminescence Geochronology of Pleistocene Slack Water Deposits in the Frasassi Hypogenic Cave System, Italy," in 250 Million Years of Earth History in Central Italy: Celebrating 25 Years of the Geological Observatory of Coldigioco. Editors C. Koeberl and D. Bice (New York, NY: Geological Society of America Special Paper), 542, 411-428. doi:10.1130/ 2019.2542(23)

Moore, D. M., and Reynolds, R. C., Jr. (1997). X-ray Diffraction and the Identification and Analysis of clay Minerals. Oxford: Oxford University Press, 378.

Moore, P. D., Webb, J. A., and Collinson, M. (1991). Pollen Analysis. second edition. London: Blackwell Sci. Publication, 216.

Murray, A. S., Thomsen, K. J., Masuda, N., Buylaert, J. P., and Jain, M. (2012). Identifying Well-Bleached Quartz Using the Different Bleaching Rates of Quartz and Feldspar Luminescence Signals. Radiat. Measurements. 47, 688-695. doi:10.1016/j.radmeas.2012.05.006

Neuhuber, S., Plan, L., Gier, S., Hintersberger, E., Lachner, J., Scholz, D., et al. (2021). Numerical Age Dating of Cave Sediments to Quantify Vertical Movement at the Alpine-Carpathian Transition in the Plio- and Pleistocene. GeolCarp. 71, 41. doi:10.31577/GeolCarp.71.6.5

Nikler, L. (1973). Novi Prilog Poznavanju Oledbe Velebita [A New Contribution to the Knowledge of the Velebit Mt. Glaciation - in Croatian]. Geološki Vjesnik 25, 109-112.

Pacher, M., and Stuart, A. J. (2009). Extinction Chronology and Palaeobiology of the Cave bear (Ursus Spelaeus). Boreas 38 (2), 189-206. doi:10.1111/j.15023885.2008.00071.x

Palmer, A. (1991). Origin and Morphology of limestone Caves. Geol. Soc. America Bull. 103, 1-21. doi:10.1130/0016-7606(1991)103<0001:OAMOLC >2.3.CO;2

Paunović, M., Jambrešić, G., Brajković, D., Malez, V., and Mauch Lenardić, J. (1999). Last Glacial Settlement of Croatia: Catalogue of Fossil Sites Dated to the OIS 2\&3. Acta Geologica. 26/2, 27-70.

PDF-4/Minerals (2020). International Centre for Diffraction Data. SN: MIND 200133-4545. Berlin: Springer.

Prelogović, E. (1975). Neotektonska Karta SR Hrvatske [Neotectonic Map of Croatia - in Croatian]. Geološki vjesnik 28, 97-108.

Prescott, J. R., and Hutton, J. T. (1994). Cosmic ray Contributions to Dose Rates for Luminescence and ESR Dating: Large Depths and Long-Term Time Variations. Radiat. Measurements. 23, 497-500. doi:10.1016/1350-4487(94)90086-8

Prescott, J., and Stephan, L. (1982). The Contribution of Cosmic Radiation to the Environmental Dose for Thermoluminescent Dating - Latitude, Altitude and Depth Dependencies. PACT. 6, 17-25.

Preusser, F., Degering, D., Fuchs, M., Hilgers, A., Kadereit, A., Klasen, N., et al. (2008). Luminescence Dating: Basics, Methods and Applications. E\&g Quat. Sci. J. 57, 95-149. doi:10.3285/eg.57.1-2.5

Rades, E. F., Fiebig, M., and Lüthgens, C. (2018). Luminescence Dating of the Rissian Type Section in Southern Germany as a Base for Correlation. Quat. Int. 478, 38-50. doi:10.1016/j.quaint.2016.07.055

Reimann, T., Thomsen, K. J., Jain, M., Murray, A. S., and Frechen, M. (2012). Single-grain Dating of Young Sediments Using the pIRIR Signal from Feldspar. Quat. Geochronol. 11, 28-41. doi:10.1016/j.quageo.2012.04.016

Reimer, P. J., Austin, W. E. N., Bard, E., Bayliss, A., Blackwell, P. G., Bronk Ramsey, C., et al. (2020). The IntCal20 Northern Hemisphere Radiocarbon Age Calibration Curve (0-55 Cal kBP). Radiocarbon. 62, 725-757. doi:10.1017/ RDC.2020.41

Reimer, P. J., Brown, T. A., and Reimer, R. W. (2004). Discussion: Reporting and Calibration of post-bomb ${ }^{14} \mathrm{C}$ Data. Radiocarbon. 46 (3), 1299-1304. doi:10.1017/S0033822200033154

Rhodes, E. J. (2011). Optically Stimulated Luminescence Dating of Sediments over the Past 200,000 Years. Annu. Rev. Earth Planet. Sci. 39, 461-488. doi:10.1146/ annurev-earth-040610-133425

Rudzka, D., McDermott, F., and Surić, M. (2012). A Late Holocene Climate Record in Stalagmites from Modrič Cave (Croatia). J. Quat. Sci. 27, 585-596. doi:10.1002/jqs.2550
Sarıkaya, M., Stepišnik, U., Žebre, M., Çiner, A., Yıldırım, C., Vlahović, I., et al. (2020). Last Glacial Maximum Deglaciation of the Southern Velebit Mt. (Croatia): Insights from Cosmogenic $36 \mathrm{Cl}$ Dating of Rujanska Kosa. Mediterr. Geosci. Rev. 2, 53-64. doi:10.1007/s42990-020-00030-9

Sasowsky, I. D., Šebela, S., and Harbert, W. (2003). Concurrent Tectonism and Aquifer Evolution >100,000 Years Recorded in Cave Sediments, Dinaric Karst, Slovenia. Env Geol. 44, 8-13. doi:10.1007/s00254-002-0727-4

Schmid, S. M., Bernoulli, D., Fügenschuh, B., Matenco, L., Schefer, S., Schuster, R., et al. (2008). The Alpine-Carpathian-Dinaridic Orogenic System: Correlation and Evolution of Tectonic Units. Swiss J. Geosci. 101, 139-183. doi:10.1007/ s00015-008-1247-3

Schultz, L. G. (1964). Quantitative Interpretation of Mineralogical Composition from X-ray and Chemical Data for the Pierre Shale. New York, NY: U. S. Geological Survey Professional Paper, 391-C, 31.

Sebag, D., Di Giovanni, C., Ogier, S., Mesnage, V., Laggoun-Défarge, F., and Durand, A. (2006). Inventory of Sedimentary Organic Matter in Modern Wetland (Marais Vernier, Normandy, France) as Source-Indicative Tools to Study Holocene Alluvial Deposits (Lower Seine Valley, France). Int. J. Coal Geology. 67, 1-16. doi:10.1016/j.coal.2005.08.002

Sevastjanova, I., Hall, R., and Alderton, D. (2012). A Detrital Heavy mineral Viewpoint on Sediment Provenance and Tropical Weathering in SE Asia. Sediment. Geology. 280, 179-194. doi:10.1016/j.sedgeo.2012.03.007

Sironić, A., Krajcar Bronić, I., Horvatinčić, N., Barešić, J., Borković, D., Vurnek, M., et al. (2020). "Carbon Isotopes in Dissolved Inorganic Carbon as Tracers of Carbon Sources in Karst Waters of the Plitvice Lakes, Croatia," in Stable Isotope Studies of the Water Cycle and Terrestrial Environments. Editors A. Bojar, A. Pelc, and C. Lecuyer (London: Geological Society of London), 49, 19. doi:10.1144/SP507-2020-49

Sironić, A., Krajcar Bronić, I., Horvatinčić, N., Barešić, J., Obelić, B., and Felja, I. (2013). Status Report on the Zagreb Radiocarbon Laboratory-AMS and LSC Results of VIRI Intercomparison Samples. Nucl. Instr. Methods Phys. Res. B 294, 185-188. doi:10.1016/j.nimb.2012.01.048

Sokač, B., Šušnjar, M., Bukovac, J., and Bahun, S. (1976). Osnovna Geološka Karta SFRJ 1:100000, Tumač Za List Udbina L33-128 [Guide for Basic Geological Map in Scale of 1:100,000 - Sheet Udbina L33-128 - in Croatian]. Institut Za Geološka Istraživanja, Zagreb (1965). Beograd: Savezni geološki institut, 62.

Soulet, G., Skinner, L. C., Beaupré, S. R., and Galy, V. (2016). A Note on Reporting of Reservoir 14C Disequilibria and Age Offsets. Radiocarbon. 58, 205-211. doi:10.1017/RDC.2015.22

Srdoč, D., Krajcar Bronic, I., Horvatincic, N., and Obelic, B. (1986). The increase of ${ }^{14} \mathrm{C}$ activity of dissolved inorganic carbon along the river course. Radiocarbon. $28,515-521$.

Starkey, H. C., Blackmon, P. D., and Hauff, P. L. (1984). The Routine Mineralogical Analysis of Clay-Bearing Samples. U. S. Geol. Surv. Bull. 1563, 31.

Stuiver, M., and Polach, H. A. (1977). Discussion Reporting of 14C Data. Radiocarbon 19 (3), 355-363. doi:10.1017/S0033822200003672

Surić, M., and Juračić, M. (2010). Late Pleistocene-Holocene Environmental Changes-Records from Submerged Speleothems along the Eastern Adriatic Coast (Croatia). Geologia Croatica. 63 (2), 155-169. doi:10.4154/gc.2010.13

Šušnjar, M., Sokač, B., Bahun, S., Bokovac, J., Nikler, L., and Ivanović, A. (1973). Osnovna Geološka Karta SFRJ 1:100000, List Udbina L33-128 [Basic Geological Map in Scale of 1:100,000-Sheet Udbina L33-128-in Croatian]. Institut Za Geološka Istraživanja, Zagreb (1963-1965). Beograd: Savezni geološki institut.

Talaja, M., and Kurečić, T. (2017). Geološka I Geomorfološka Opažanja U Jami Muda Labudova [Geological and Geomorphological Observations in the Muda Labudova Pit-in Croatian]. Speleolog. 65 (1), 32-41. Available at: https://hrcak. srce.hr/204711.

Tari, V. (2002). "Evolution of the Northern and Western Dinarides: a Tectonostratigraphic Approach," in "Evolution of the Northern and Western Dinarides : A Tectonostratigraphic Approach" in Continental Collision and the Tectono-Sedimentary Evolution of Forelands. Editors G. Bertotti, K. Schulmann, and S. A. P. L. Cloetingh (Germany, Copernicus): Katlenburg-Lindau), 1, 223-236. doi:10.5194/smsps-1-223-2002

Therre, S., Fohlmeister, J., Fleitmann, D., Matter, A., Burns, S. J., Arps, J., et al. (2020). Climate-induced Speleothem Radiocarbon Variability on Socotra Island from the Last Glacial Maximum to the Younger Dryas. Clim. Past. 16, 409-421. doi:10.5194/cp-16-409-2020 
Tischler, J., Töchterle, P., and Moseley, G. E. (2020). Characterization of Northeast Greenland Cave Sediments. Cave Karst Sci. 42, 100-103. doi:10.1016/02773791(94)90064-7

Trbojević Vukičević, T., and Babić, K. (2008). Nalazi Kostura Špiljskog Medvjeda (Ursus Spelaeus) Iz Cerovačkih Pećina [Finds of the Skeleton of a Cave bear (Ursus Spelaeus) from the Cerovac Caves - in Croatian]. Izdanja Hrvatskog arheološkog društva 23, 23-27. doi:10.1016/j.quaint.2014.03.046

Trefethen, J. M. (1950). Classification of Sediments. Am. J. Sci. 248, 55-62. doi:10.2475/ajs.248.1.55

Tresić Pavičić, D. (2020). Arheološko Istraživanje Donje Cerovačke (Turkaljeve) Špilje [Archaeological Research of the Lower Cerovačka (Turkaljeva) Cave - in Croatian]. Subterranea Croatica 18 (29), 60-74.

Tresić Pavičić, D., and Burmaz, J. (2019). Izvješće O Završetku Arheoloških Istraživanja U Donjoj Cerovačkoj Špilji 2019. Godine [Report on the Completion of Archaeological Research in the Lower Cerovačka Cave in 2019 - in Croatian]. Zagreb: Kaducej d.o.o., 137.

Tyson, R. V. (1995). Sedimentary Organic MatterOrganic Facies and Palynofacies. London: Chapman \& Hall, 615.

Valen, V., Lauritzen, S. E., and Lovlie, R. (1997). Sedimentation in a High-Latitude Karst Cave: Sirijordgrotta, Nordland, Norway. Norsk Geologisk Tidsskrift 77, 233-250.

Van Geel, B. (2002). "Non-Pollen Palynomorphs,". Terrestrial, Algal and Silicaceous Indicators. Editors J. P. Smol, H. J. B. Birks, and W. M. Last (Dordrecht: Kluwer Academic Publishers), Vol. 3, 99-119. doi:10.1007/0306-47668-1_6

Velde, B., and Meunier, A. (2008). The Origin of Clay Minerals in Soils and Weathered Rocks. Berlin Heidelberg: Springer-Verlag, 406. doi:10.1007/978-3540-75634-7

Velić, J., Velić, I., Kljajo, D., Protrka, K., Škrabić, H., and Špoljar, Z. (2017). A Geological Overview of Glacial Accumulation and Erosional Occurrences on the Velebit and the Biokovo Mts., Croatia. Mining-Geology-Petroleum Bull. 32 (4), 77-96. doi:10.17794/rgn.2017.4.8

Wacha, L., Montanari, A., Lomax, J., Fiebig, M., Luthgens, C., Korbar, T., et al. (2019). "Last Glacial Maximum Giant Sand Dunes on the Island of Vis, Croatia," in 250 Million Years of Earth History in Central Italy: Celebrating 25 Years of the Geological Observatory of Coldigioc. Editors C. Koeberl and D. M. Bice (New York, NY: Geological Society of America Special Paper), 459-470. doi:10.1130/2019.2542(26)

Wacha, L., Rolf, C., Hambach, U., Frechen, M., Galović, L., and Duchoslav, M. (2018). The Last Glacial Aeolian Record of the Island of Susak (Croatia) as Seen from a High-Resolution Grain-Size and Rock Magnetic Analysis. Quat. Int. 494, 211-224. doi:10.1016/j.quaint.2017.08.016

Weaver, C. E. (1967). The Distribution and Identification of Mixed-Layer Clays in Sedimentary Rocks. Am. J. Mineral. Soc. 41 (3-4), 202-221.

Weaver, C. E. (1989). Clays, Muds, and Shales. Amsterdam: Elsevier, 721.

White, E. L. (2019). in "Chapter 21 - Breakdown" in Encyclopedia of Caves. Editors W. B. White, D. C. Culver, and T. Pipan. Third Edition (Boston: Elsevier Academic Press), 187-194. doi:10.1016/B978-0-12-814124-3.00020-0
White, W. B. (2007). Cave Sediments and Paleoclimate. J. cave Karst Stud. 69 (1) 76-93. doi:10.1007/978-1-4419-9118-8_9

Whitlock, C., and Larsen, C. (2002). "Charcoal as a Fire Proxy," in Tracking Environmental Change Using Lake Sediments. Developments in Paleoenvironmental Research. Editors J. P. Smol, H. J. B. Birks, W. M. Last, R. S. Bradley, and K. Alverson (Dordrecht: Springer), Vol. 3, 75-97. doi:10.1007/0-306-47668-1_5

Wintle, A. G. (1973). Anomalous Fading of Thermo-Luminescence in Mineral Samples. Nature. 245, 143-144. doi:10.1038/245143a0

Wintle, A. G. (2008). Luminescence Dating: where it Has Been and where it Is Going. Boreas. 37, 471-482. doi:10.1111/j.1502-3885.2008.00059.x

Wood, G. D., Gabriel, A. M., and Lawson, J. C. (1996). "Palynological Techniques: Processing and Microscopy" in Palynology: Principles and Applications. Editors J. Jansonius and D. C. McGregor (New York, NY: Am. Assoc. Stratigr. Palynol. Found.), 1, 29-50.

Wróblewski, W., Gradzinski, M., Motyka, J., and Stankovic, J. (2017). Recently growing subaqueous flowstones: Occurrence, petrography, and growth conditions. Quat. Int. 437, 84-97. doi:10.1016/j.quaint.2016.10.006

Zhang, J., Rolf, C., Wacha, L., Tsukamoto, S., Durn, G., and Frechen, M. (2018). Luminescence Dating and Palaeomagnetic Age Constraint of a Last Glacial Loess-Palaeosol Sequence from Istria, Croatia. Quat. Int. 494, 19-33. doi:10.1016/j.quaint.2018.05.045

Zupan Hajna, N., Bosák, P., Pruner, P., Mihevc, A., Hercman, H., and Horáček, I. (2020). Karst Sediments in Slovenia: Plio-Quaternary Multi-Proxy Records. Quat. Int. 546, 4-19. doi:10.1016/j.quaint.2019.11.010

Zupan Hajna, N. (2019). "Dinaric Karst-Geography and Geology," in "Chapter 40 - Dinaric Karst-Geography and Geology" in Encyclopedia of Caves. Editors W. B. White, D. C. Culver, and T. Pipan. Third Edition (Boston: Elsevier Academic Press), 353-362. doi:10.1016/B978-0-12-8141243.00039-X

Zupan Hajna, N., Mihevc, A., Bosák, P., Pruner, P., Hercman, H., Horáček, I., et al. (2021). Pliocene to Holocene Chronostratigraphy and Palaeoenvironmental Records from Cave Sediments: Račiška Pečina Section (SW Slovenia). Quat. Int. in press. doi:10.1016/j.quaint.2021.02.035

Conflict of Interest: Author DP, was employed by the company Kaducej d.o.o.

The remaining authors declare that the research was conducted in the absence of any commercial or financial relationships that could be construed as a potential conflict of interest.

Copyright (C) 2021 Kurečić, Bočić, Wacha, Bakrač, Grizelj, Tresić Pavičić, Lüthgens, Sironić, Radović, Redovniković and Fiebig. This is an open-access article distributed under the terms of the Creative Commons Attribution License (CC BY). The use, distribution or reproduction in other forums is permitted, provided the original author(s) and the copyright owner(s) are credited and that the original publication in this journal is cited, in accordance with accepted academic practice. No use, distribution or reproduction is permitted which does not comply with these terms. 